\title{
Geochemistry of Crustally Derived Leucocratic Igneous Rocks From the Ulugh Muztagh Area, Northern Tibet and Their Implications for the Formation of the Tibetan Plateau
}

\author{
L. W. MCKENNA ${ }^{1}$ \\ Department of Earth, Atmospheric and Planetary Science, Massachusetts Institute of Technology, Cambridge
}

\section{J. D. WALKER}

Department of Geology, University of Kansas, Lawrence

\begin{abstract}
Igneous rocks collected from the Ulugh Muztagh, $200 \mathrm{~km}$ south of the northem rim of the Tibetan Plateau $\left(36^{\circ} 28^{\prime} \mathrm{N}, 8^{\circ} 29^{\prime} \mathrm{E}\right)$, form intrusive and extrusive bodies whose magmas were produced by partial melting of upper-crustal, primarily pelitic, source rocks. Evidence for source composition includes high initial ${ }^{87} \mathrm{~S} /{ }^{86} \mathrm{Sr}$ ratios $(\sim 0.711$ to 0.713$),{ }^{206} \mathrm{~Pb} /{ }^{204} \mathrm{~Pb}$ ratios of $18.72,{ }^{207} \mathrm{~Pb} /{ }^{204} \mathrm{~Pb}$ of 15.63 and ${ }^{208} \mathrm{~Pb} /{ }^{204} \mathrm{~Pb}$ of 38.73 . The degree of melting in the source region was increased by significant heating via in situ decay of radioactive nuclides; a reasonable estimate for the heat production rate in the source is $3.9 \times 10^{-6} \mathrm{~W} / \mathrm{m}^{3}$. The crystallization ages and cooling ages [Burchfiel et al., 1989] of the earliest intrusive rocks within the suite suggest crustal thickening began in the northern Tibetan Plateau before $10.5 \mathrm{Ma}$, with maximum average unroofing rates in this part of the Tibetan Plateau for the period between 10.5 and $4 \mathrm{Ma}$ at approximately $<2 \mathrm{~mm} / \mathrm{yr}$. The Ulugh Muztagh flows are at the northem edge of a widely distributed field of Plio-pliestocene volcanic rocks in the north-central Tibetan Plateau. The crustally derived rocks described here are an endmember component of a wide mixing zone of hybrid magmas; the other end-member forms mantlederived, potassic basanites and tephrites exposed in the central section of the Plio-Pleistocene field. The compositional trends in these belts strike east-west, at high angle to the $\mathrm{N} 30 \mathrm{E}$ strike of the Plateau itself. Consideration of the chemical data and published geophysical data argue that the subPlateau mantle is mechanically detached from the overlying continental lithosphere, and that in this section of the plateau the thermal structure of the asthenosphere is not responsible for the formation or maintenance of the plateau's topography.
\end{abstract}

\section{INTRODUCTION}

The collision (between 40 and $50 \mathrm{Ma}$ ) and subsequent convergence of the Indian subcontinent and the Eurasian continent created both the Himalayan Range and the Tibetan Plateau [Molnar, 1988]. Although recent years have seen an enormous increase in our knowledge of the geology of the greater Himalayan orogen, little is still known of the geology of the Tibetan Plateau and its surrounding areas. Our limited knowledge is derived primarily from teleseismic data, a small number of seismic lines, and remote sensing studies of the area [Molnar, 1988] and, with the exception of the Royal Society-Academica Sinica Geotraverse results, few directed field observations are available. The samples of igneous rocks discussed in this report were collected from the Ulugh Muztagh region of the north-central Tibetan Plateau (Figure 1) and provide an opportunity to constrain both the thermal structure of the Tibetan crust and mantle, and the rates of crustal unroofing within the northern Tibetan Plateau. In addition, analysis of these samples

\footnotetext{
${ }^{1}$ Now at the Department of Geology, University of Kansas, Lawrence
}

Copyright 1990 by the American Geophysical Union allow inferences to be made on both the composition of the Tibetan crust and the character of Miocene to Pliocene magmatism. Aspects of the structural geology in the Ulugh Muztagh area are discussed by Burchfiel et al. [1989].

The Tibetan Plateau is typically divided into three structural blocks; from north to south these are the Kunlun, Qiangtang and Lhasa blocks (Figure 1; Chang et al. [1986]). The Jinsha Suture, dated as end-Triassic [Harris et al., 1988], is the surface trace of the north-dipping [Harris et al., 1988] or south-dipping [Pearce and Mei, 1988] subduction zone which separated the Kunlun and Qiangtang terrains prior to collision. As described by Burchfiel et al. [1989], Ulugh Muztagh lies astride a series of ophiolitic fragments which may mark the western extension of the Jinsha Suture into this area. The mean age of crustal material in the Kunlun block some $500 \mathrm{~km}$ east of Ulugh Muztagh, along the Royal Society Geotraverse route, is constrained by the isotopic composition and ages of syn-collision to post-collision granitiods exposed in the Kunlun Mountains to be midProterozoic [Harris et al., 1988]. Neodymium model ages of sedimentary rocks collected along the Geotraverse route also give mid-Proterozoic ages. According to the geological map of the Tibetan Plateau [Ministry of Geology and Natural Resources, 1980], country rocks of the Kunlun terrain include Carboniferous to Permian rocks juxtaposed with units of Triassic and Cretaceous age. South of the suture, upper Triassic [Burchfiel et al., 1989] to lower to middle 


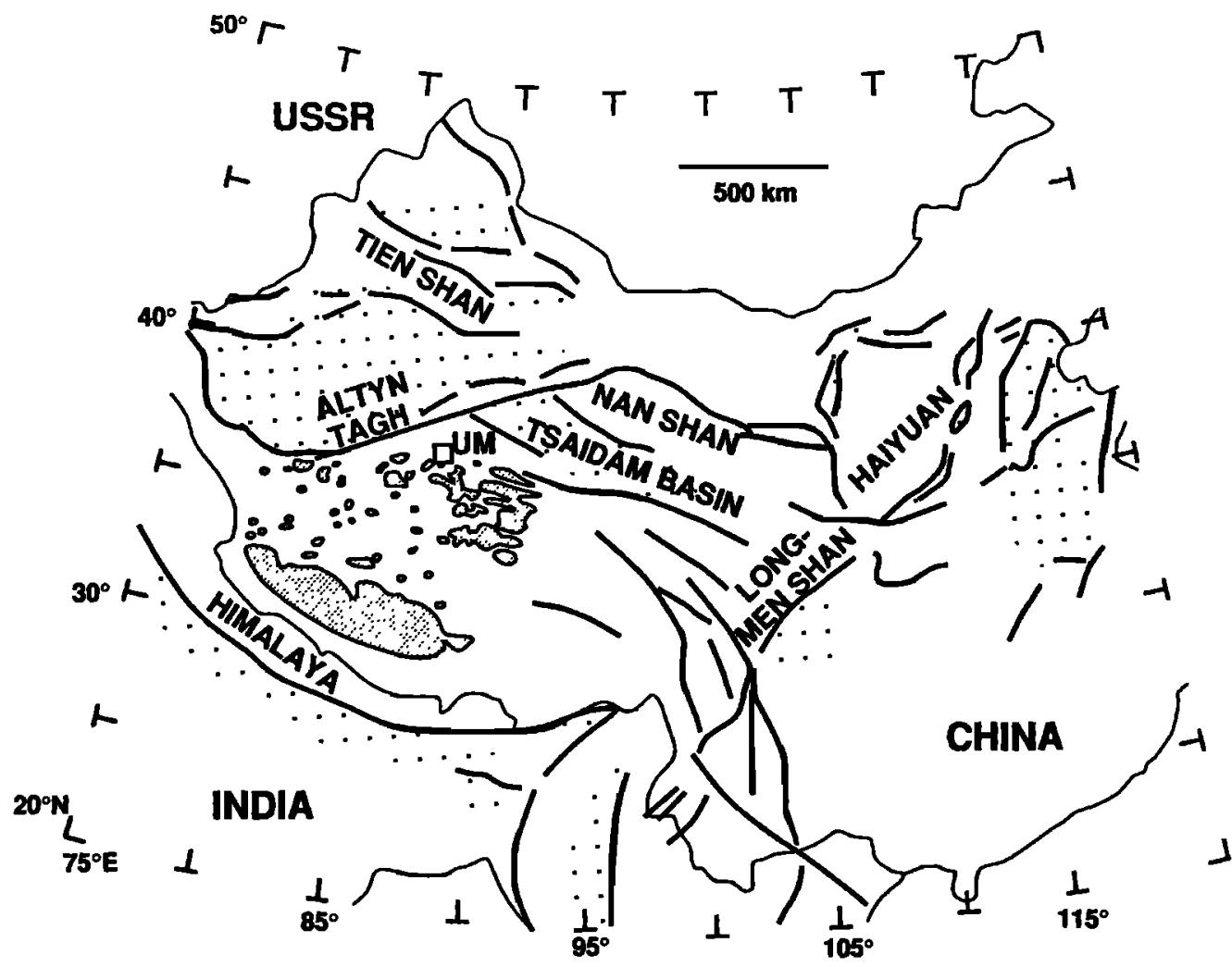

Fig. 1. Location map and regional geologic setting of Ulugh Muztagh ("Great Snowy Mountain"), which is situated $200 \mathrm{~km}$ south of the northern edge of the Tibetan Plateau, central Asia. Areas of Cenozoic magmatism are shaded, basins are stippled, strikeslip faults are shown with half arrows indicating relative movements, thrust faults are shown with barbs on upper plate. Dashed lines with open barb are suture zones; from north to south they are the Jinsha, Banggong and Indus-Zangpo Sutures, respectively. International boundaries are shown by thin lines, degrees North latitude and East longitude are also shown.

Cretaceous sediments form the majority of the pre-Cenozoic rocks. The apparent discrepancy of the age of the suture (end Triassic) and that of rocks which it truncates (middle Cretaceous) is probably due to the poorly known ages of the sedimentary units in this largely inaccessible region.

The broad structure of the Tibetan Plateau as illustrated by geophysical data was recently reviewed by Molnar [1988]. From his review of seismic data, Molnar concluded that the depth to the Moho in the Ulugh Muztagh region of the north-central Tibetan Plateau $\left(36^{\circ} 28^{\prime} \mathrm{N}, 8^{\circ} 29^{\prime} \mathrm{E}\right)$ is some 65 $\pm 5 \mathrm{~km}$. While such a crustal thickness would generally be considered abnormally high, it appears to be $5 \mathrm{~km}$, and perhaps $10 \mathrm{~km}$, thinner than the crust of surrounding areas within the plateau. Molnar [1988] also concluded that upper asthenospheric temperatures for this area are higher than surrounding areas, and cautiously suggests temperatures at the crust-mantle boundary may be as high as $1300 \mathrm{~K}$. The neotectonics of this area of the plateau are dominated by north-directed thrusting of the Kunlun Shan and Tibetan Plateau over the Tarim Basin at a rate estimated by Molnar et al. [1987] at $6 \pm 4 \mathrm{~mm} / \mathrm{yr}$.

The earliest (and, until recently, the only) reports of the geology of the area are those of Littledale [1886]. Backstrom and Johanssen [1907] and Norin [1946]. Somewhat more recently, Deng [1978] reported the petrology and major element chemistry of a number of samples of Plio-Pleistocene volcanic rocks from a transect south of Ulugh Muztagh. These rocks included ultra potassic leucitites, phonolites and pyroxene andesites; these samples are discussed in more detail below (see Regional Relationships). Additional major element determinations of a subset of these samples, along with new trace element data, were included by Pearce and Mei [1988], who discussed the major and trace element chemistry of volcanic rocks encountered along the 1985 Royal Society-Academia Sinica Geotraverse Route, approximately $500 \mathrm{~km}$ east of Ulugh Muztagh.

Country rocks in the study area proper consist of metamorphosed, openly folded, Triassic sedimentary rocks, intruded by granitoid rocks of Miocene age [Burchfiel et al., 1989]. These intrusives were thought by these workers to be responsible for the andalusite-grade, regional-scale contact metamorphism of the country rocks in the area. Mineral separates of these intrusive rocks give ${ }^{40} \mathrm{Ar} /{ }^{39} \mathrm{Ar}$ cooling ages of 10.5 to $8.4 \mathrm{Ma}$ ([Burchfiel et al., 1989], see of this paper for a summary of the geochronologic data). The intrusive rocks are overlain, above a local unconformity, by boulder conglomerate overlain in turn by a sequence of now dissected extrusive rocks, principally ash flow tuffs and flows. These flows are dated at $4.0 \pm 0.1 \mathrm{Ma}$ $\left({ }^{40} \mathrm{Ar} /{ }^{39} \mathrm{Ar}\right.$, biotite fusion and K-feldspar, [Burchfiel et al., 1989]).

Field relations allow division of the magmatic rocks into three groups: (1) intrusive samples BKSP, UBTG, 2MGR, and QTD which intrude the metamorphosed basement; (2) samples (defined below as the Potassium Poor samples) 
which crop out as small plugs (UM10, KSPO) and dikes (QTL) that intrude the Triassic sandstones east of the Ulugh Muztagh; and (3) the capping Ulugh Muztagh extrusive series (MV1B, UM1B, MV2, UMVU, UM3V, UMQP).

\section{PROCEDURES}

Samples were taken as 1 to $3 \mathrm{~kg}$ blocks from outcrops or, in the case of samples UM10, BKSP, and UBTG, in moraine and stream deposits below outcrops, using an ice ax as the sampling tool. Weathered faces were removed with a diamond cutoff saw, and cut faces were polished with $\mathrm{SiC}$ to remove sawmarks. All samples were cleaned by boiling and then ultrasounding in deionized water, then dried and hand crushed. Whole rock powders were made from 50 to $100 \mathrm{~g}$ splits using a tungsten carbide shatterbox.

Major and trace elements were determined by $X$ ray fluorescence on a fully automated Rigaku $X$ ray spectrometer at the University of Kansas. Major elements were run as fused glass beads from whole rock powders, with $\mathrm{Li}_{2} \mathrm{~B}_{4} \mathrm{O}_{7}$ flux; trace elements were nun as powdered disks with cellulose binder. Uncertainties, based on repeated analyses of standards, are $0.5-1 \%$ for major elements, $1-2 \%$ for trace elements with concentrations greater than $50 \mathrm{ppm}$, and 5 $10 \%$ for trace elements with concentrations less than 50 ppm.

Isotope ratios and concentrations were determined through isotope dilution techniques [Hart and Brooks, 1977]. Strontium and rubidium data were collected at the Massachusetts Institute of Technology (on a $23 \mathrm{~cm}, 60^{\circ}$ spectrometer) and University of Kansas (VG Sector); samples analyzed at both institutions give identical results within analytical uncertainties. Strontium data are reported relative to NBS 987 standard ${ }^{87} \mathrm{Sr} /{ }^{86} \mathrm{Sr}=0.71024$, and are normalized relative to ${ }^{86} \mathrm{Sr} /{ }^{88} \mathrm{Sr}=0.1194$. Precisions are $0.1 \%$ for $\mathrm{Rb}$, $0.03 \%$ for $\mathrm{Sr}$ and $<0.008 \%$ for ${ }^{87} \mathrm{Sr} /{ }^{86} \mathrm{Sr}$. Strontium and rubidium blank levels are insignificant for the analyses reported. All $\mathrm{Pb}$ analyses were conducted at the University of Kansas, where blank levels for $\mathrm{Pb}$ analyses are 150-300 pg. All samples are fractionation corrected; the fractionation factor of $0.1 \pm 0.05 \% / a m u$ was determined by repeated analyses of NBS 982 common $\mathrm{Pb}$ standard.

Instrumental neutron activation analysis (INAA) was carried out at MIT; procedures and analysis techniques are reported by Ile and Frey [1984] and Lindstrom and Korotev [1982]. High U concentrations in the samples required corrections for $\mathrm{La}, \mathrm{Ce}, \mathrm{Nd}$, and $\mathrm{Sm}$ due to interferences from $\mathrm{U}$ fission products [Korotev, 1985]; corrections are listed in Appendix 2. Because $B$ has an exceptionally large thermal neutron capture cross section, tourmaline-bearing samples (QTL, UM10, and QTD) may have received anomalously low neutron fluxes [King et al., 1988]. However, modal tourmaline is low in these samples, and elemental concentrations of $\mathrm{Rb}$ determined by INAA, XRF and ID agree within uncertainties, suggesting that this problem is not significant for these samples. Reproducibility of the analyses are approximately $1.5 \%$; the uncertainties quoted with the data include all sources of errors, including $U$ corrections.

\section{RESULTS}

\section{Petrography}

The petrography of the samples are briefly described below, summarized in Table 1, and described in more detail in Appendix 1. The extrusive samples, with the exception of UMQP, all contain similar phenocryst assemblages of quartz+sanidine+plagioclase $\left(\mathrm{An}_{20-40}\right)$ +cordierite+biotitet tourmaline (rare) in microlitic to glassy groundmasses. The rocks occur as ash flow tuffs (UMVU, UM3V, MV2, and UMQP) and rhyolitic flows (UM1B, MV1B). Similar modal abundances for five of the samples suggests that syneruptional crystal sorting was not significant in the ash flow tuffs, except for UMQP which has no modal plagioclase and exceptionally high $\mathrm{K}_{2} \mathrm{O}$. The intrusive samples (BKSP, 2MGR, UBTG) are dominantly hypidiomorphic to panidiomorphic granular granites, which show some signs of post crystallization strain. The typical assemblages is potassium feldspar+quartz+ plagioclase +biotite tmuscovite tkaolinite(?). Visible accessory phases are rare, generally limited to anhederal, turbid (xenocrystic ?) zircons, and prismatic, clear allanite. Samples QTL and UM10 are quartz+plagioclase+tourmaline (minor) porphyry trondhjemites with a microlitic quartz and plagioclase groundmass. Sample KSPO is a granodiorite containing coarse orthoclase phenocrysts+quartz+plagioclase with medium-grained biotite and muscovite. Allanite is a common accessory mineral.

\section{Major Elements}

Major element compositions of the samples are shown in Table 1. Silica contents range from 71.1 to 75.5 weight percent, $\mathrm{Fe}_{2} \mathrm{O}_{3}{ }^{*}$ (all $\mathrm{Fe}$ as $\mathrm{Fe}_{2} \mathrm{O}_{3}$ ) from 0.15 to $1.5 \mathrm{wt} \%$, $\mathrm{MgO}$ from 0.0 to $0.25 \mathrm{wt} \%$, and total alkalies from 7.2 to $9.6 \mathrm{wt} \%$. Oxide variation diagrams for $\mathrm{K}_{2} \mathrm{O}$ and $\mathrm{Fe}_{2} \mathrm{O}_{3}$ * versus $\mathrm{SiO}_{2}$ are shown in Figures $2 a$ and $2 b$. The majority of the samples define a trend of approximately constant $\mathrm{K}_{2} \mathrm{O}$ (5 wt \%), and slightly decreasing $\mathrm{Fe}_{2} \mathrm{O}_{3}$ * contents (1.5-1 wt $\%$ ), over a $\mathrm{SiO}_{2}$ of 71.0 to 74.5 wt \%. (As noted above, syneruptional sorting has apparently impoverished UMQP in plagioclase, resulting in high potash.) Three samples (UM10, QTL and KSPO) do not follow this trend, showing low $\mathrm{K}_{2} \mathrm{O}$ and very low $\mathrm{Fe}_{2} \mathrm{O}_{3}{ }^{*}$ (as low as $0.2 \mathrm{wt} \%$ ). These samples are henceforth referred to as the potassium-poor samples.

\section{Trace Elements}

Trace element data are given in Table 2. All samples (except for QTL and UM10, which consistently differ from the other samples) show high $\mathrm{U}, \mathrm{Rb}$, and $\mathrm{Ba}$ concentrations and low Sr and transition metal concentrations. Rare earth element (REE) distributions (see Figure $3 a$ ) are consistently light REE (LREE) enriched, concave upward, with large, negative Eu anomalies and constant $\mathrm{Yb}$ concentrations. Trace element concentrations of samples QTL and UM10 vary inversely to those of the other samples: $\mathrm{S}_{\mathrm{r}}$ is high, $\mathrm{Rb}$, $\mathrm{Ba}$ and $\mathrm{U}$ are low, and $\mathrm{Pb}$ is very low. LREE abundances in the potassium-poor rocks are generally lower than, and high REE (HREE) abundances approximately equal to, abundances in the remainder of the samples. Despite these differences, the REE distributions of the potassium-poor samples are grossly similar to those of the other Ulugh Muztagh samples.

\section{$S r$ and $\mathrm{Pb}$ Isotopic Data}

Isotopic data are shown in Table 3, and isotope correlation plots for both $\mathrm{Sr}$ and $\mathrm{Pb}$ are presented in Figures 4 and 5 . 


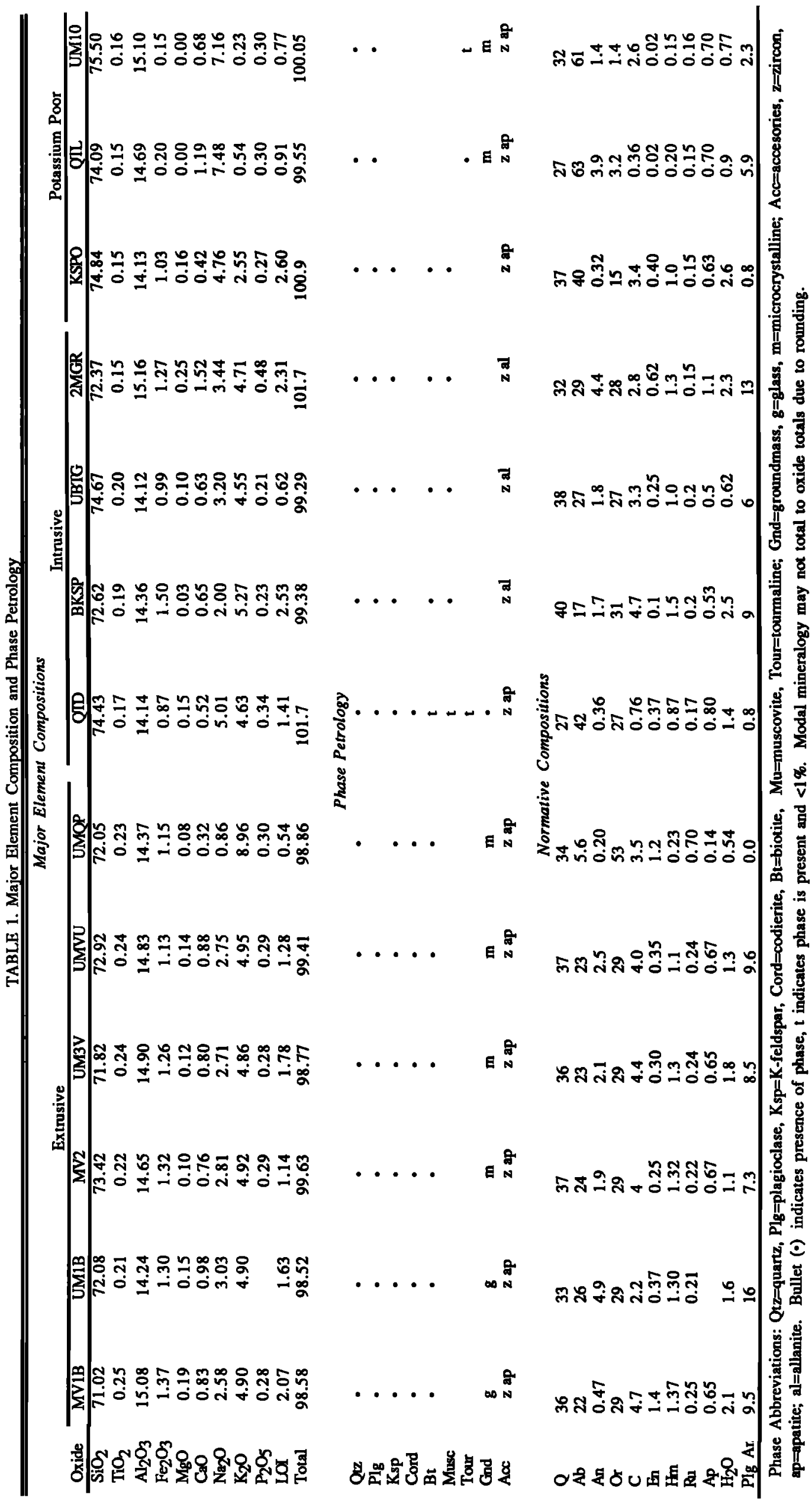




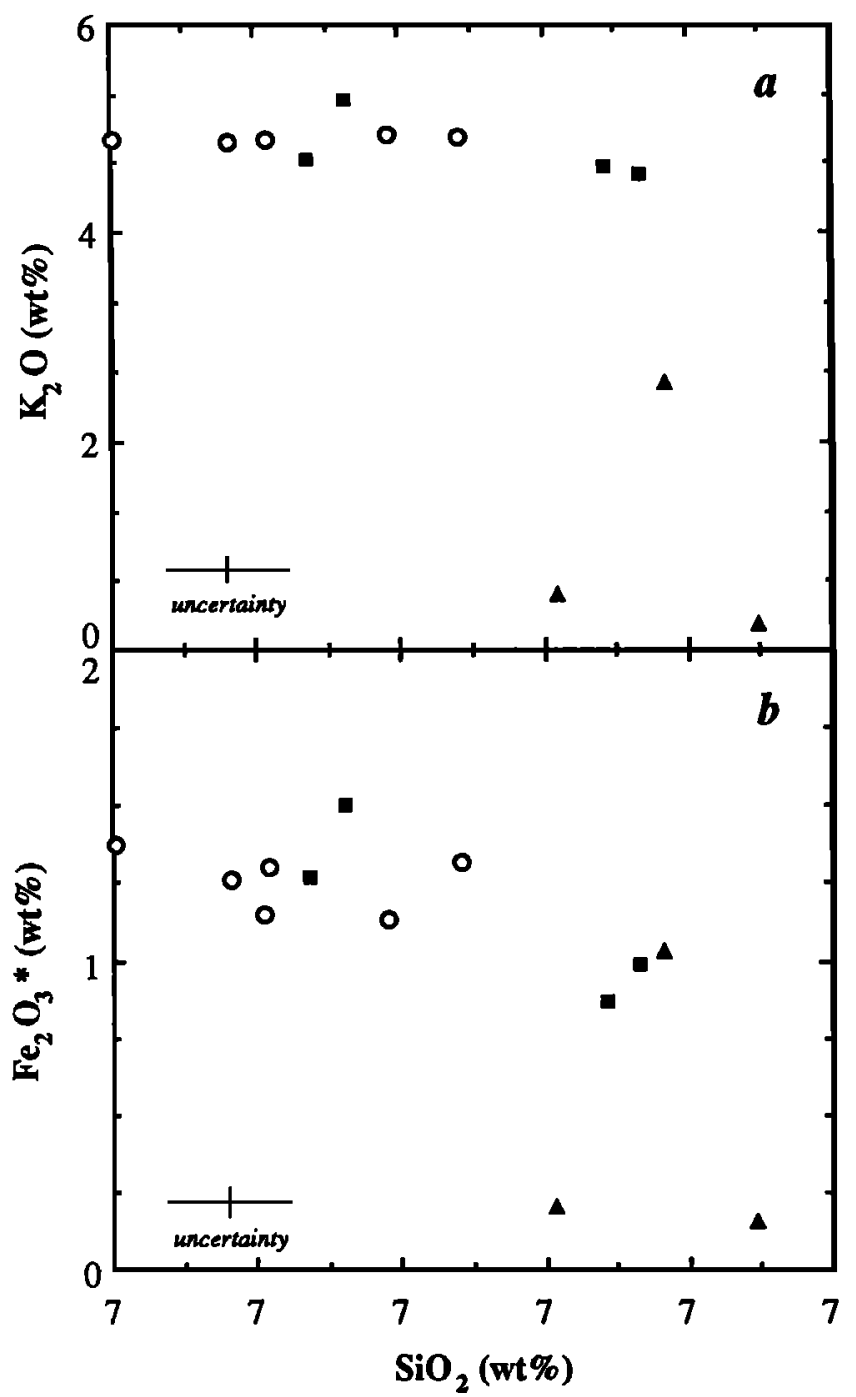

Fig. 2. Whole rock oxide variation diagrams for the Ulugh Muztagh samples. On this and all subsequent diagrams, symbols are open circles for extrusive rocks; filled squares for intrusive rocks; and filled triangles for potassium-poor samples. (a) $\mathrm{K}_{2} \mathrm{O}$ versus $\mathrm{SiO}_{2}$ (wt \%) shows approximately constant $\mathrm{K}_{2} \mathrm{O}$ over the range of $\mathrm{SiO}_{2}$ for intrusive and extrusive samples; the potassium-poor samples (triangles) show very low $\mathrm{K}_{2} \mathrm{O}$ at relatively high $\mathrm{SiO}_{2}$. Sample UMQP plots above the field. (b) $\mathrm{Fe}_{2} \mathrm{O}_{3} *$ (all $\mathrm{Fe}$ as $\mathrm{Fe}_{2} \mathrm{O}_{3}$ ) versus $\mathrm{SiO}_{2}$ though scattered, exhibits a small decrease with increasing silica; the Ulugh Muzagh samples are characterized by low transition-metal contents, including $\mathrm{Fe}, \mathrm{Mg}, \mathrm{Cr}$, and $\mathrm{Ni}$.

The trondhjemitic, potassium-poor samples (UM10 and QTD) have ${ }^{87} \mathrm{Sr} /{ }^{86} \mathrm{Sr}$ of approximately 0.7118 and ${ }^{87} \mathrm{Rb} /{ }^{86} \mathrm{Sr}$ less than 1 , while the remainder of the measured samples have higher ${ }^{87} \mathrm{Sr}^{86} \mathrm{~S}_{\mathrm{r}}$ ratios of $0.71555(2)$ to $0.71817(3)(95 \%$ uncertainties in the last digit quoted for all measurements are shown by the numbers in parentheses). Variations in $\mathrm{Pb}$ isotope compositions of the Ulugh Muztagh samples are the inverse of the $\mathrm{Sr}$ isotope variations (Figure 5), with potassium-poor samples showing higher ${ }^{206} \mathrm{~Pb} /{ }^{204} \mathrm{~Pb}$ and slightly higher ${ }^{208} \mathrm{~Pb} /{ }^{204} \mathrm{~Pb}$ than the remainder of the samples; the latter cluster within uncertainties at ${ }^{206} \mathrm{~Pb} /{ }^{204} \mathrm{~Pb}=18.73(5), \quad{ }^{207} \mathrm{~Pb} /{ }^{204} \mathrm{~Pb}=15.63(5)$ and ${ }^{208} \mathrm{~Pb} /{ }^{204} \mathrm{~Pb}=38.74(10)$.

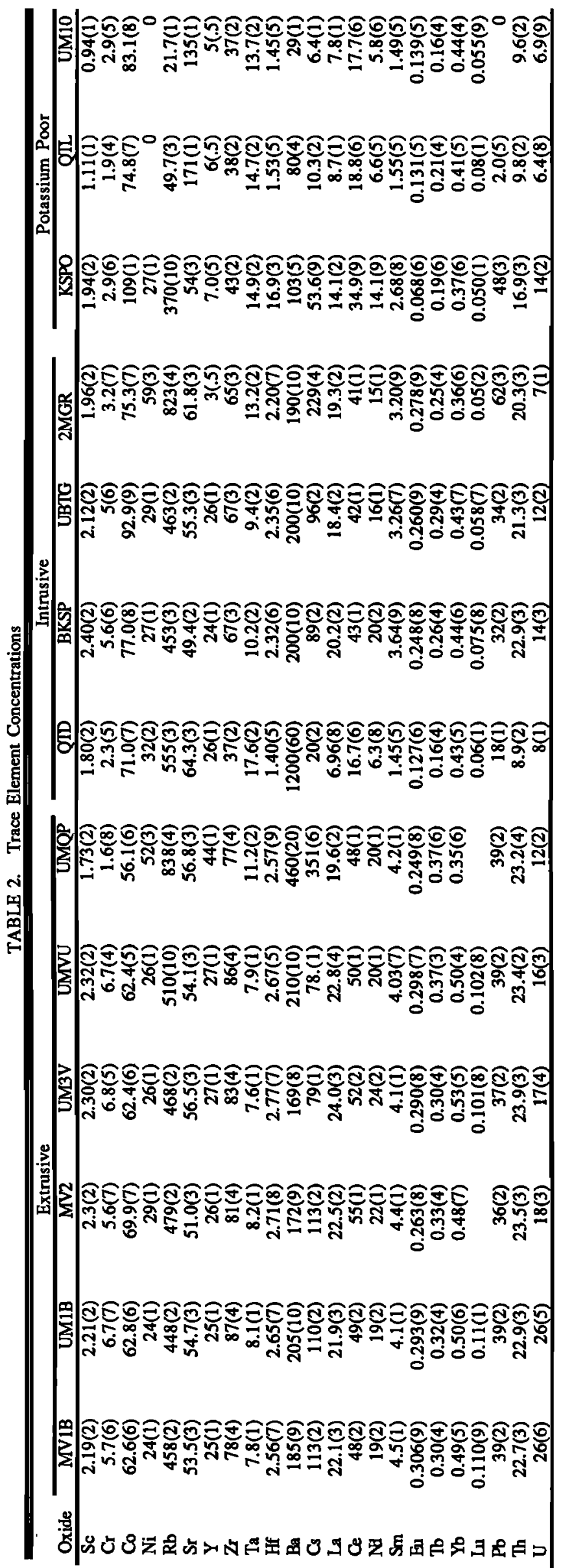




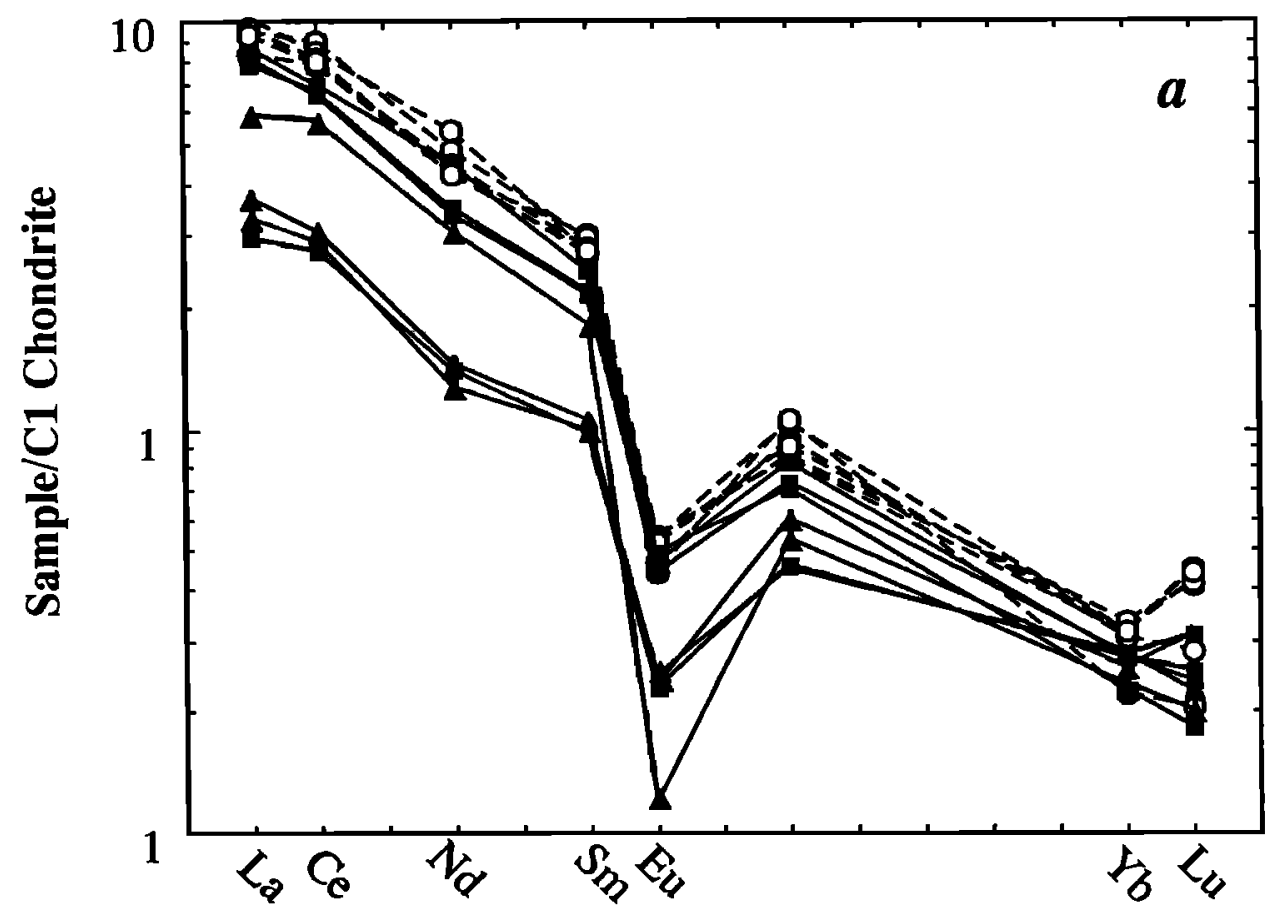

\section{Element}

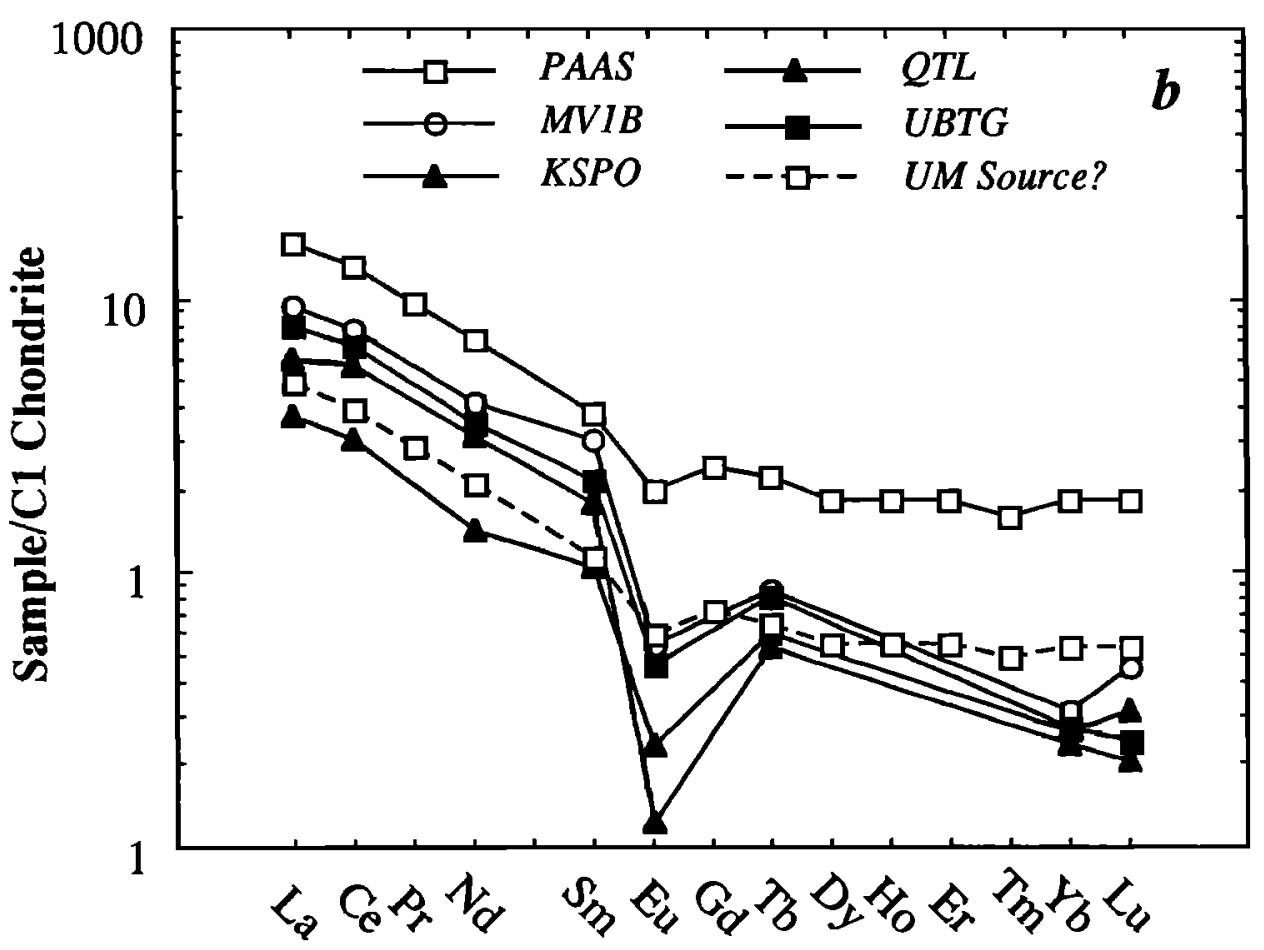

\section{Element}

Fig. 3. Chondrite nomalized [Anders and Ebihara, 1982] REE abundances for the Ulugh Muztagh samples. Data in Table 2, symbols as in Figure 2. (a) All samples show $(\mathrm{L} \cdot \mathrm{a} / \mathrm{Yb})_{\mathrm{cn}}$ greater than 10; large, negative Eu anomalies; and similar $\mathrm{Yb}$ and $\mathrm{Lu}$ contents. Extrusive rocks show little variation, intrusive rocks have generally lower LREE abundances than the extrusive rocks. Potassium-poor samples vary from relatively LREE-enriched (KSPO) to LREE-poor (UM10, QTL); HREE contents for all three samples are roughly constant. (b) Representative REE abundances for the three samples groups, the post-Archean Australian Shale composite [Nance and Taylor, 1976] (PAAS, open squares with solid line), and 0.3-PAAS (open squares, douted line). A possible model for the REE abundances in the Ulugh Muztagh source region is given by the 0.3.PAAS line. See text for discussion. 


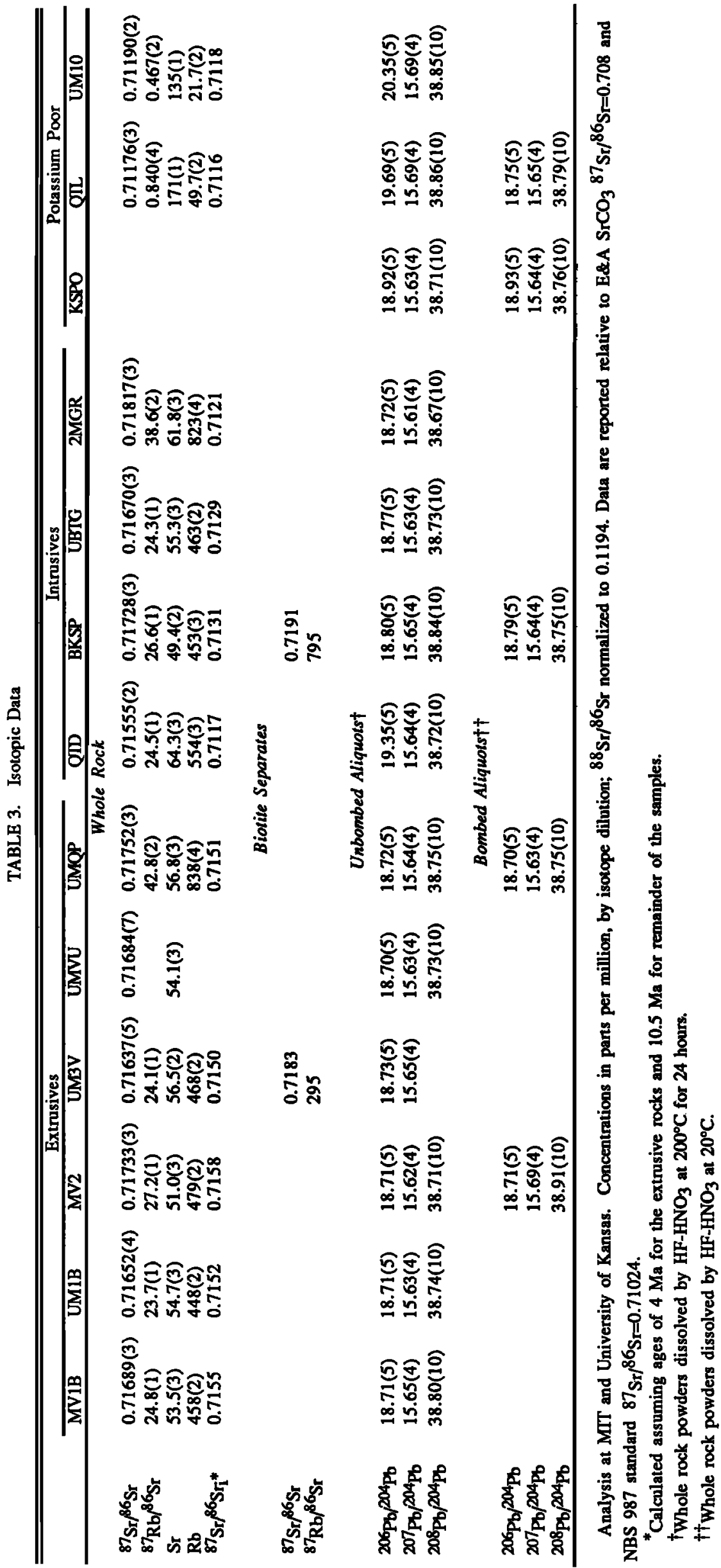




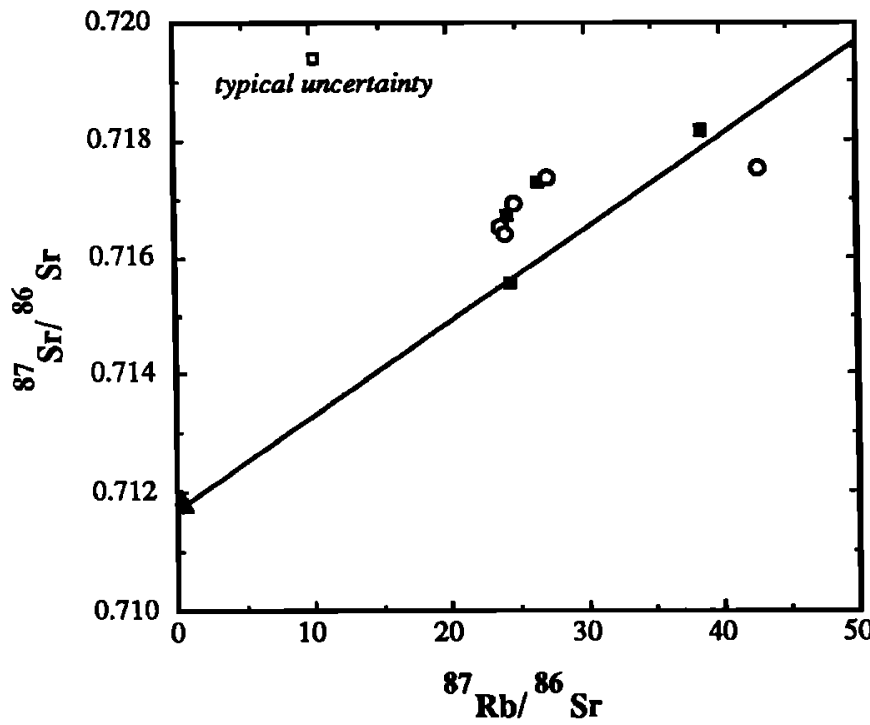

Fig. 4. Sr isotope correlation diagram for the Ulugh Muztagh samples. Symbols as in Figure $2 ; 2 \sigma$ uncertainties are smaller than the symbols. Although the samples do not define an isochron, a reference line with a slope equivalent to an age of $11 \mathrm{Ma}$ is shown. The potassium-poor samples have very low ${ }^{87} \mathrm{Rb} / 86 \mathrm{Sr}$ ratios and indicate their initial ratios of -0.7117 . The intrusive and extrusive samples have similar contemporary ${ }^{87} \mathrm{Sr} /{ }^{86} \mathrm{Sr}$ ratios, despite the difference in crystallization times of at least 4-6.5 Ma [Burchfiel et al., 1989]. Average initial ${ }^{87} \mathrm{Sr}^{86} \mathrm{Sr}$ ratios for the intrusive and extrusive rocks (corrected for an age of 10.5 and $4.0 \mathrm{Ma}$, respectively) are $0.7123(7)$ and $0.7154(5)$.

\section{Discussion}

\section{Petrogenesis of the Ulugh Muztagh Samples}

We hypothesize below that the composition and mineralogy of the extrusive and intrusive sample groups are consistent with derivation by partial melting of chemically similar pelitic or psammitic source rocks. Ideally, evidence for such an argument would include observations and analyses of the restitic material. The Tibetan Plateau is, however, hardly an ideal place in which to conduct field research, and such observations and samples are not available. Therefore we support our hypothesis by comparing the composition of the Ulugh Muztagh samples to the expected composition of liquids produced by partial melting of crustal material. The characteristics of partial melting of pelitic rocks precludes detailed petrogenetic modeling of the process because (1) a wide variety of phases are potentially stable in the restite; (2) the apparent partition coefficients for many of these phases are poorly, if at all, constrained, and; (3) the apparent partition coefficients of these phases can vary strongly with liquid composition in highly silicic liquids. Instead, we make quantitative arguments on the composition of the source area, the degree of partial melting in the source area, and the temperature of the system during melting by comparing the composition of the melts to those expected through partial melting of crustal materials. We then present evidence that the potassium-poor samples were produced by a combination of partial melting of amphibolitic or tonalitic source rocks, along with variable addition of a potassium feldspar component to the liquid. Each sample group is discussed in turn, beginning with the extrusive rocks.
Extrusive rocks. Field relationships of these units indicate that they were extruded approximately synchronously, an observation supported by the similar ${ }^{40} \mathrm{Ar} /{ }^{39} \mathrm{Ar}$ ages (biotite and K-feldspar) for two of the samples (MV2 and UM1B) of $4.1 \pm 0.1$ and $4.0 \pm 0.1 \mathrm{Ma}$ [Burchfiel et al., 1989]. The major element variations of these rocks are similar to those produced experimentally by melting of pelitic schist. The $\mathrm{K}_{2} \mathrm{O}$ versus $\mathrm{SiO}_{2}$ and $\mathrm{Al}_{2} \mathrm{O}_{3}$
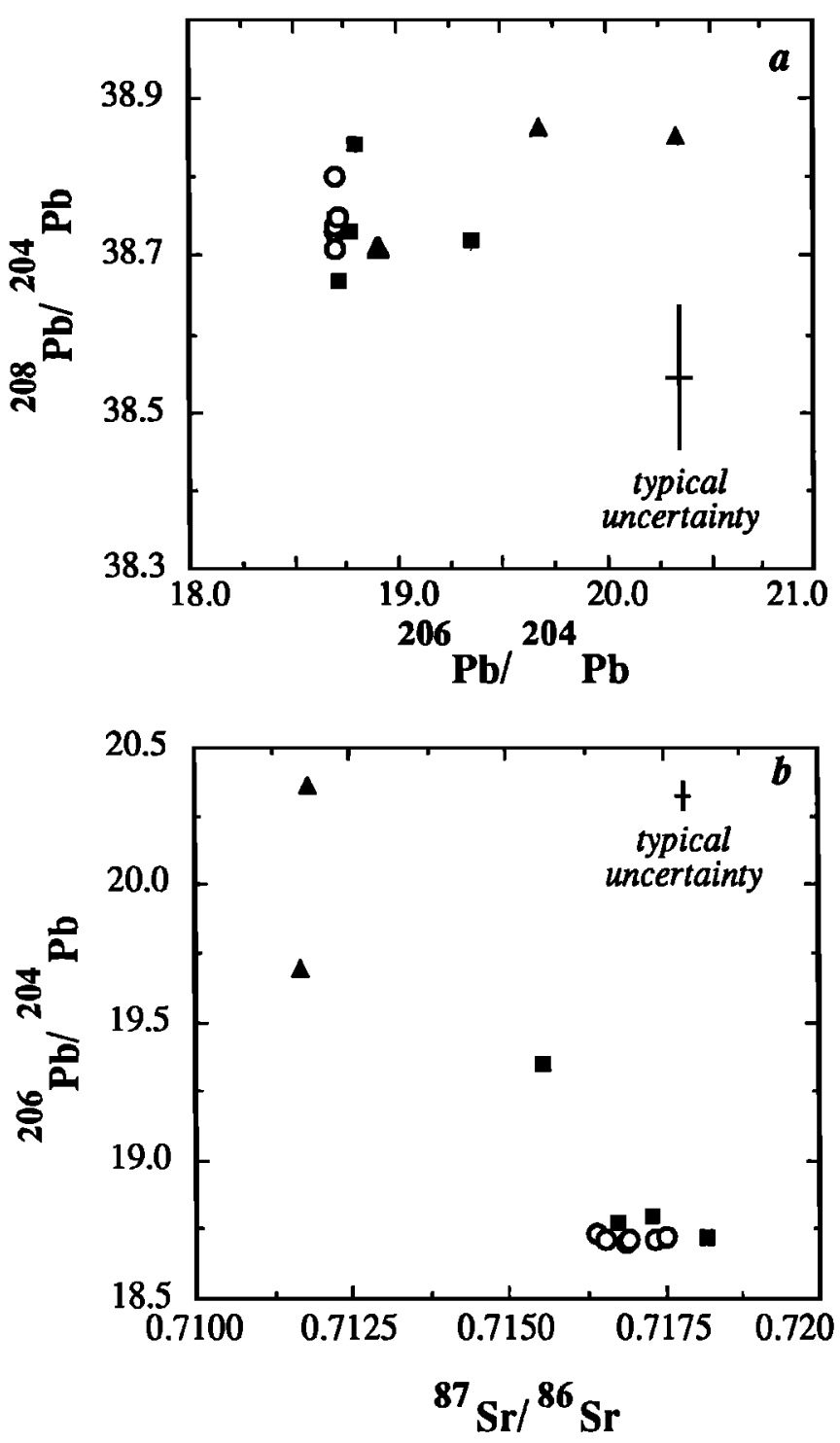

Fig. 5. Lead-lead and $\mathrm{Pb}-\mathrm{Sr}$ isotope correlation diagrams for the Ulugh Muztagh samples, symbols as in Figure 2, typical uncertainties $(2 \sigma)$ are shown. (a) ${ }^{208} \mathrm{~Pb} / 204 \mathrm{~Pb}$ versus ${ }^{206} \mathrm{~Pb} /{ }^{204} \mathrm{~Pb}$ plot shows the extrusive samples and all but one of the intrusive samples (QTD) plotting within uncertainty at ${ }^{206} \mathrm{~Pb} /{ }^{204} \mathrm{~Pb}=18.72$ and ${ }^{208} \mathrm{~Pb} /{ }^{204} \mathrm{~Pb}=38.73$. Potassium-poor samples QTD and UM10 (triangles) have considerably higher ${ }^{206} \mathrm{~Pb} /{ }^{204} \mathrm{~Pb}$ ratios, due to their very low $\mathrm{Pb}$ contents of $<2 \mathrm{ppm}$. With sample KSPO, the potassium-poor samples define a trend that terminates at the primary extrusive-intrusive group. (b) The plot of ${ }^{206} \mathrm{~Pb} /{ }^{204} \mathrm{~Pb}$ versus ${ }^{87} \mathrm{Sr} /{ }^{86} \mathrm{Sr}$ shows variable ${ }^{87} \mathrm{Sr} /{ }^{86} \mathrm{Sr}$ with constant ${ }^{206} \mathrm{~Pb} /{ }^{204} \mathrm{~Pb}$ for both the intrusive and extrusive rocks. The potassium-poor samples scatter at high ${ }^{206} \mathrm{~Pb} /{ }^{204} \mathrm{~Pb}$ and low ${ }^{87} \mathrm{Sr} /{ }^{86} \mathrm{Sr}$. QTD appears anomalous, with high ${ }^{206} \mathrm{~Pb} /{ }^{204} \mathrm{~Pb}$ and lower ${ }^{87} \mathrm{Sr} /{ }^{86} \mathrm{Sr}$. 
versus $\mathrm{SiO}_{2}$ variations for the extrusive samples are shown superimposed upon the 10-kbar, "pelitic, fluid absent " melt compositions of Vielzeuf and Holloway [1988] in Figure 6. These compositions represent partial melts of a quartzplagioclase(An30)-kyanite-muscovite-biotite-

garnettstaurolitetchlorite source with a pelitic bulk composition, melted over a temperature range of $1150 \mathrm{~K}$ to $1520 \mathrm{~K}$. In these experiments the $\mathrm{SiO}_{2}$ content of the melt decreases monotonically with increasing temperature. Also shown in these figures are the water-saturated haplogranite minima of Nekvasil [1988], calculated at 5 and $10 \mathrm{kbar}$.

As shown in Figure 6, the composition of the Ulugh Muztagh extrusive rocks is distinctly different than compositions of haplogranite melts, as modeled by Nekvasil's calculated compositions [Nekvasil, 1988]. As noted by Nekvasil [1988, p. 979], "partial melts derived from source regions with relatively high $\mathrm{H}_{2} \mathrm{O}$ contents should cluster around the haplogranite minimum composition unless the An[orthite] content of the source area is high." Because the Ulugh Muztagh extrusive rocks do not cluster about any composition, we infer that the rocks were derived either from an $\mathrm{H}_{2} \mathrm{O}$-undersaturated or anorthite-rich source area.

Further insight into the chemical composition of the source area is gained by comparing the experimental pelitic melts of Vielzeuf and Holloway [1988] to the Ulugh Muztagh data. The Ulugh Muztagh extrusive rocks show a smooth variation in $\mathrm{K}_{2} \mathrm{O}-\mathrm{Al}_{2} \mathrm{O}_{3}-\mathrm{SiO}_{2}$ composition space that parallels, although is not coincident with, the experimentally derived melt composition. Higher potash contents in the Ulugh Muztagh samples could be due to small differences in anorthite contents of the source area. The calculations of Nekvasil [1988] indicate that increasing the An content of plagioclase in the source from 30 to 50 mole percent would cause an increase in both quartz and orthoclase components in the melt. The effect of adding 5 wt \% quartz and 5 wt \% orthoclase to one of the experimental melts is illustrated by the arrow in Figure 6 . The resultant change in melt composition is sufficient to explain the differences in potash contents between the experimental liquids of Vielzeuf and Holloway [1988] and the Ulugh Muztagh extrusive rocks. The lower alumina contents in the Ulugh Muztagh samples relative to the Vielzeuf and Holloway [1988] liquids is also partly explained by increases in the quartz and orthoclase components in the melt. The sensitivity of the alumina composition to pressure changes (as shown by Nekvasil's calculated minima) suggests that the pressure in the source area may also have influenced the alumina content of the Ulugh Muztagh melts. This discussion indicates that the Ulugh Muztagh magmas have compositions consistent with derivation by partial melting of a source of pelitic composition: the $\mathrm{SiO}_{2}$ contents of the magmas would then correspond, according to the data of Vielzeuf and Holloway [1988], to a temperature and volume fraction of melt $\left(F_{v}\right)$ of approximately 1100 $1200 \mathrm{~K}$ and $60 \%$, respectively. This value for $F_{v}$ is an approximation only and probably represents an upper limit estimate for the actual degree of partial melting in the source. An estimate of the relative differences in $F_{v}$ for the extrusive rocks can be made by assuming that La acted completely incompatibly during melting, in which case the relative ratio in $F_{v}$ is equal to the ratio of $\mathrm{La}$ concentrations

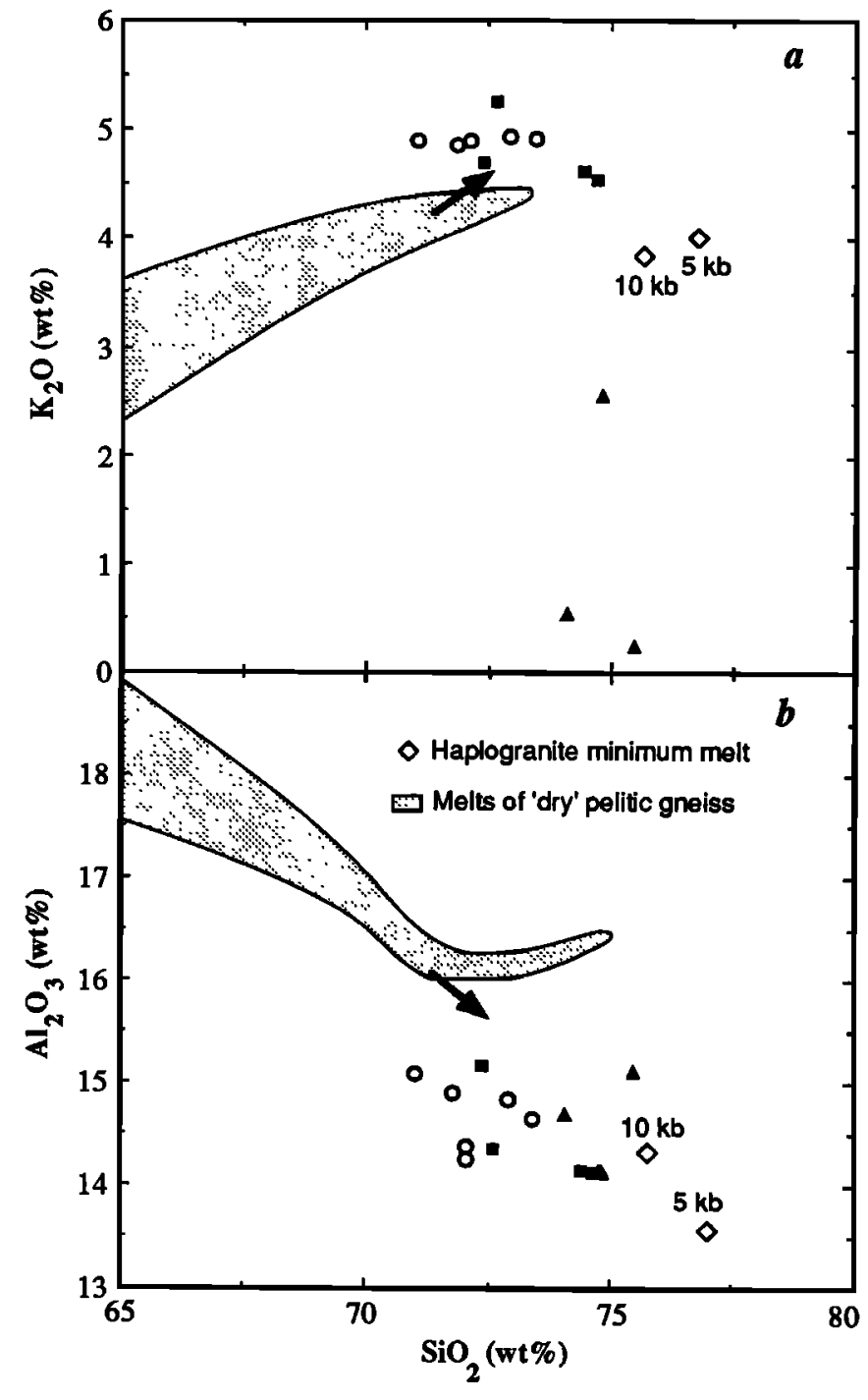

Fig. 6. Oxide variation diagrams for laboratory melting experiments of Vielzeuf and Holloway [1988] (shaded field) and the calculated dry haplogranite minima of Nekvasil [1988] at 5 and 10 kbar. The data from Vielzeuf and Holloway [1988] represent the measured composition of a melt produced by fluid-absent partial melting (at $10 \times 10^{8} \mathrm{~Pa}$ ) of a pelitic-composition source rock; $\mathrm{SiO}_{2}$ decreases with increasing degree of melting. Superimposed upon the melt data are the data for the Ulugh Muztagh samples (symbols as in Figure 2). (a) $\mathrm{K}_{2} \mathrm{O}$ versus $\mathrm{SiO}_{2}$ illustrates the similarities in bulk composition of the experimentally determined melts and the Ulugh Muztagh intrusive and extrusive samples; the potassium-poor samples (triangles) show no relationship to the partial melt composition. The potash composition of the Ulugh Muztagh samples is parallel to, but greater than, the trend of the Vielzeuf and Holloway data. This difference is probably due to higher anorthite contents in the Ulugh Muztagh source area, which increases melts quartz and $\mathrm{K}$-feldspar components. The change in melt composition due to addition of $5 \mathrm{wt} \%$ quartz and $\mathrm{K}$-feldspar is shown by the arrow leading from the shaded field. (b) The $\mathrm{Al}_{2} \mathrm{O}_{3}$ versus $\mathrm{SiO}_{2}$ for data from Vielzeuf and Holloway [1988] demonstrates the relatively low alumina contents of the Ulugh Muztagh samples compared to the $10 \times 10^{8} \mathrm{~Pa}$ melts. Note the slight increase in $\mathrm{Al}_{2} \mathrm{O}_{3}$ with decreasing $\mathrm{SiO}_{2}$ in the Ulugh Muztagh extrusive samples, a trend which parallels that in the experimental melts. The differences in alumina may be due to lower pressure of fusion in the Ulugh Muztagh source region. 
in the samples. The extreme La ratio for the extrusive rocks is 1.2 , suggesting that the variation in $F_{v}$ was small.

Additional evidence that the extrusive rocks were produced by melting of a pelitic source is provided by the $\mathrm{Sr}$ and $\mathrm{Pb}$ isotope ratios of the samples. The $\mathrm{Pb}$ data are shown superimposed upon Zartman and Doe's [1981] $\mathrm{Pb}$ composition diagrams in Figures $7 a$ and $7 b$. All extrusive samples plot tightly within or adjacent to the "Pelagic Sediments" field in both variation diagrams, and plot externally to fields containing $80 \%$ of measured upper crustal, lower crustal and mantle derived rocks. The measured ${ }^{87} \mathrm{Sr} /{ }^{86} \mathrm{Sr}$ values for the extrusive samples range from $0.71636(2)$ to $0.71735(8)$; recalculating these ratios to correct for postcrystallization decay (based on a $4.0 \pm 0.1$ $\mathrm{Ma}$ age from ${ }^{40} \mathrm{Ar} /{ }^{39} \mathrm{Ar}$ geochronology [Burchfiel et al., 1989] gives a source ${ }^{87} \mathrm{Sr} /{ }^{86} \mathrm{Sr}$ of $0.7154(5)$. This high value falls well within the "crustal" field of Faure's [1986] $\mathrm{Rb} / \mathrm{Sr}$ evolution diagram (his Figure 10.4), and requires a source area with a high time-integrated $\mathrm{Rb} / \mathrm{Sr}$ ratio.

Miller [1985, p. 674] described 12 "Criteria for Identifying Pelitic Parentage of Igneous Rocks," reproduced here as Table 4 , which includes five criteria involving major element chemistry, four involving trace elements, and three involving isotope ratios. With the data described above, only eight of these tests are possible. Comparison of the criteria in Table 4 with the data in Tables 1 through 4 shows that all pelitic parentage criteria are met or surpassed by the extrusive rocks (with the exception of UMQP) collected from Ulugh Muztagh. We conclude that although our knowledge of source area chemistry and the chemography of melting relationships is imprecise, the compositions of the Ulugh Muztagh extrusive rocks are consistent with derivation as a partial melt of a pelitic source area. The degree of partial melting is broadly constrained at $50-60 \%$, at a temperature of $1100-1200 \mathrm{~K}$.

Intrusive rocks. The geochemical, geochronological and petrological data presented above suggest that the extrusive rocks analyzed in this study form a genetically related, comagmatic series. However, the relationship between these extrusive rocks, the intrusive rocks (UBTG, QTD, 2MGR, and BKSP) and the potassium-poor samples (KSPO, UM10, and QTL) exposed in Ulugh Muztagh is less certain. Evidence for a pelitic source area for the intrusive samples is suggested by evidence similar to that used for the extrusive samples. The $\mathrm{K}_{2} \mathrm{O}$ and $\mathrm{Al}_{2} \mathrm{O}_{3}$ variations for the intrusive rocks are illustrated in Figure 6 along with the experimentally determined pelitic partial melts of Vielzeuf and Holloway [1988]. The intrusive rocks have similar to higher $\mathrm{SiO}_{2}$ and lower $\mathrm{Al}_{2} \mathrm{O}_{3}$ and $\mathrm{K}_{2} \mathrm{O}$ than the extrusive rocks. By comparison to the experimentally produced liquids of Vielzeuf and Holloway [1988], temperatures of formation for the magmas represented by the Ulugh Muztagh intrusive rocks range from $<1040 \mathrm{~K}$ to $1150 \mathrm{~K}$. Because the degree of partial melting within a source of pelitic composition changes dramatically within this temperature range (10-60\%, [Vielzeuf and Holloway, 1988]), it is possible only to suggest a broad range of $F_{v}$, from 15 to $60 \%$. Again assuming that the LREE acted completely incompatibly during melting, the relative difference in $F_{v}$ is small, $<1.1$.

Lead and strontium isotope ratios of the intrusive rocks also argue for a source region of pelitic composition. Strontium isotope ratios for some of the intrusive samples must be recalculated to account for postcrystallization decay. Crystallization ages for these rocks are not available: however, three samples have been dated by the ${ }^{40} \mathrm{Ar} /{ }^{39} \mathrm{Ar}$ method and give ages of $10.5 \pm 0.1 \mathrm{Ma}$ (UBTG, Muscovite plateau) to $8.4 \pm 0.1 \mathrm{Ma}$ (QTD, K-feldspar total gas). Thus a minimum crystallization age for the intrusive suite is $\mathbf{1 0 . 5}$ $\mathrm{Ma}$, and recalculation of initial isotope ratios based on this age will represent maximum estimates for the initial ratios. Age-corrected $\mathrm{Pb}$ isotope ratios are not considered significant enough $(<0.05)$ to require their use in the discussion. Lead isotope data are presented in Figure 7, superimposed upon Zartman and Doe's [1981] $\mathrm{Pb}$ composition diagram. With the exception of sample QTD, the intrusive rocks plot, like the extrusive rocks, within or adjacent to the pelagic sediments field. Initial ${ }^{87} \mathrm{Sr} /{ }^{86} \mathrm{Sr}$ ratios range from 0.7123 to 0.7133 , and are higher than the ${ }^{87} \mathrm{Sr} /{ }^{86} \mathrm{Sr}$ mantle evolution curve of Faure [1986], suggesting the intrusive magmas formed by melting of a source with "crustal" composition. Comparison of the Miller's [1985] criteria in for pelitic parentage in Table 4 with the data in Tables 1 through 4 show that all pelitic parentage criteria except for normative corundum and slightly high $\mathrm{Na}_{2} \mathrm{O}$ in QTD are met or surpassed by the intrusive rocks collected from Ulugh Muztagh.

The ${ }^{40} \mathrm{Ar} /{ }^{39} \mathrm{Ar}$ cooling ages for the intrusive and extrusive rocks exposed at Ulugh Muztagh imply minimum emplacement ages for these units of 10.5 and $4.0 \mathrm{Ma}$ respectively. Despite these age differences, the extrusive and intrusive samples plot together on the $\mathrm{Sr}$ isotope correlation diagram in Figure 4 . Correcting for their respective ages, the intrusive and extrusive rocks have distinct average initial ${ }^{87} \mathrm{Sr} /{ }^{86} \mathrm{Sr}$ ratios of $0.7123(7)$ and $0.7154(5)$, respectively. The scatter in the initial ratios may reflect $\mathrm{Sr}$ isotope heterogeneity of the source area; such heterogeneity in leucocratic rocks formed by partial melting of sediments is common, as discussed by, amongst others, Le Fort [1981].

Potassium poor samples. The three potassium-poor samples (KSPO, UM10, and QTL) differ substantially from both the intrusive and extrusive rocks discussed above. The most striking differences, seen in Figures $2 a$ and $2 b$ and

TABLE 4. Criteria for Identifting Peltic Source Areas

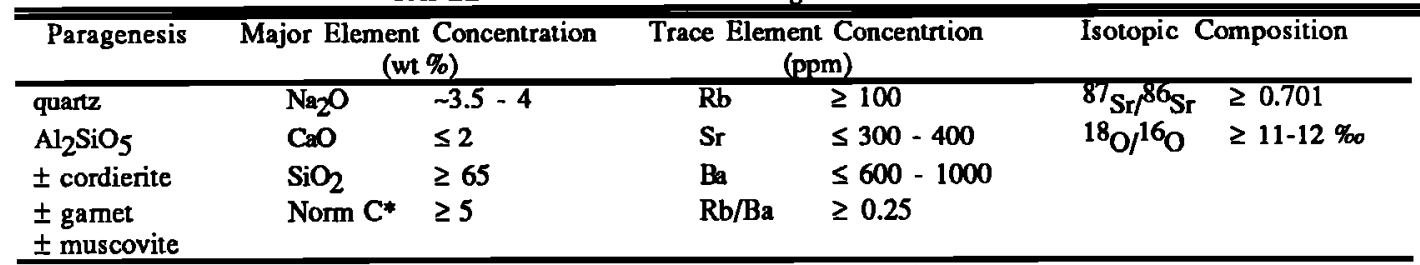

Modified from Miller [1985, Table 3]. Sr-Nd isotope relations are not shown.

* Normative Corundum 

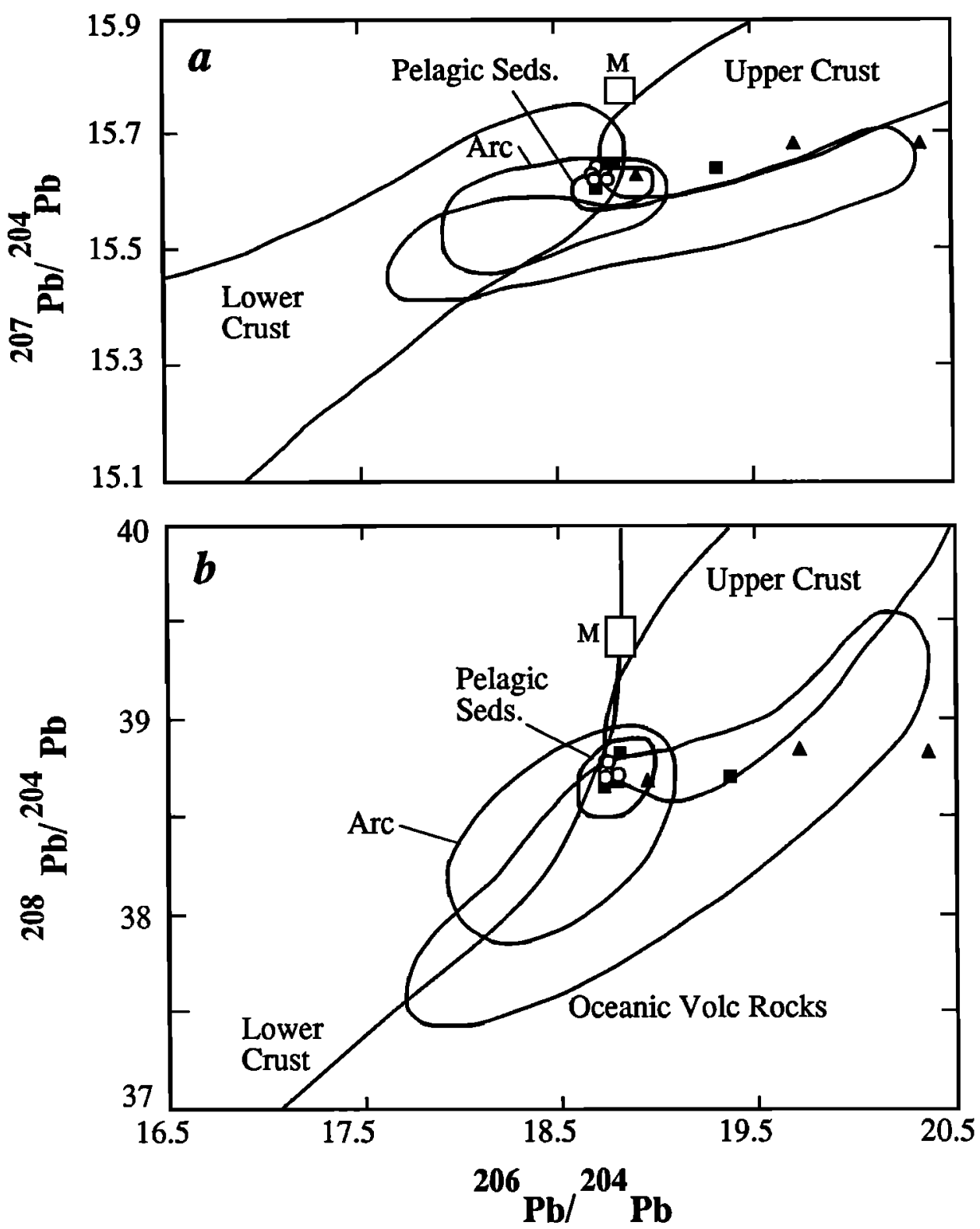

Fig. 7. Lead isotope data for the Ulugh Muztagh samples (typical $2 \sigma$ uncertainties are shown in Figure 5) superimposed upon the reservoir summary diagram of Zartman and Doe [1981]. Solid lines enclose approximately $80 \%$ of all data points derived from each reservoir, including "probable average values" for pelagic sediments of Mesozoic and Cenozoic age. Range of whole rock $\mathrm{Pb}$ ratios for the Manaslu leucogranite (Nepalese Himalaya [Vidal et al., 1982] are shown by box labeled "M." (a) The ${ }^{207} \mathrm{~Pb} /{ }^{204} \mathrm{P}$ versus ${ }^{206} \mathrm{~Pb} / 204 \mathrm{~Pb}$ data. All samples except for QTL, UM10 (triangles) and QTD (solid square) plot within or adjacent to the Pelagic Sediments field. As noted in text, correction for postcrystallization decay would probably relocate QTL and UM10 to within the Pelagic Sediment field. (b) The ${ }^{208} \mathrm{~Pb} /{ }^{204} \mathrm{~Pb}$ versus ${ }^{206} \mathrm{~Pb} /{ }^{204} \mathrm{~Pb}$ data also plot within the Pelagic Sediments field, except for samples QTL, UM10 (triangles) and QTD (solid square). As noted in the text, correction of QTL and UM10 ratios for postcrystallization decay would relocate the samples to within the Pelagic Sediment field.

Tables 2 and 3, are the low to very low $\mathrm{K}_{2} \mathrm{O}, \mathrm{Fe}_{2} \mathrm{O}_{3}, \mathrm{MgO}$, $\mathrm{Pb}$ and $\mathrm{Rb}$ contents of the potassium-poor samples at $\mathrm{SiO}_{2}$ contents equivalent to the remainder of the Ulugh Muztagh samples. As noted in Appendix 1, samples UM10 and QTL are trondhjemites composed entirely of porphyritic plagioclase, quartz, and rare tourmaline in a microcrystalline groundmass of the same minerals, with accessory apatite and very rare zircon. Although these samples have 0.8 and 2.6 wt \% normative K-feldspar, respectively, thin section examination and repeated staining of slabs failed to show any modal K-feldspar in these two samples, while the relatively $\mathrm{K}_{2} \mathrm{O}$-rich, granodioritic $\mathrm{KSPO}$ has 13.5 wt \% normative K-feldspar. The chemical relationship between these samples and the remainder of the Ulugh Muztagh samples is investigated in Figure 8, a Pearce-type variation diagram [Nichols, 1988] displaying the variation of $3 \mathrm{~K} / \mathrm{Yb}$ versus $\mathrm{Si} / \mathrm{Yb}$. In this diagram, addition of components with a cation ratio $\mathrm{K}: \mathrm{Si}$ of $a: b$ has slope $3 a / b$; thus the trend 


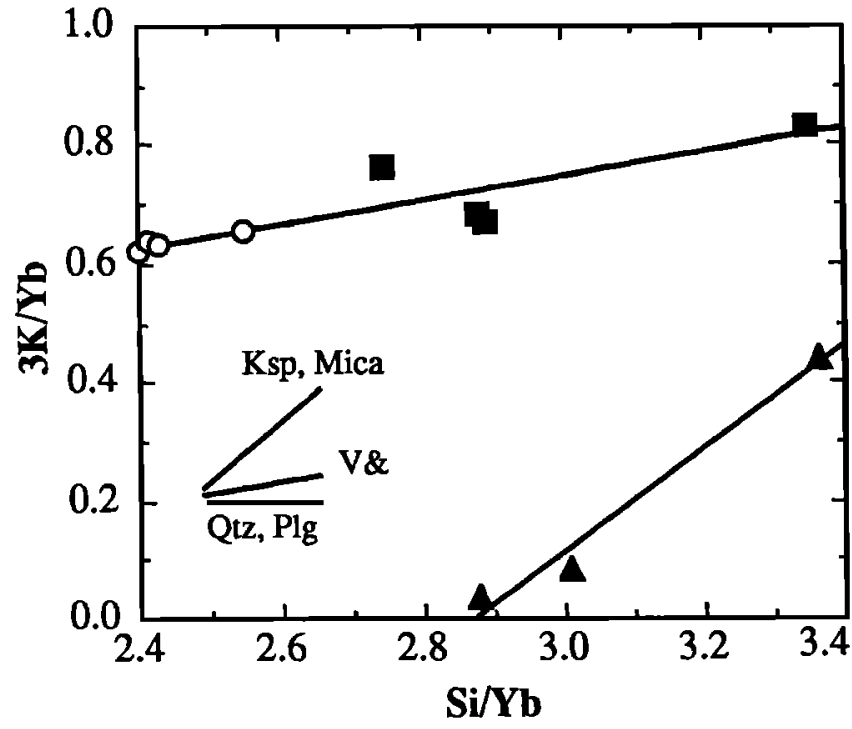

Fig. 8. A Pearce-type element ratio diagram [Nichols, 1988] for $\mathrm{K}$ and $\mathrm{Si}$. On this diagram, trends controlled by minerals with $\mathrm{K}: \mathrm{Si}$ ratios of 1:3 (K-feldspar, micas) will have a slope of unity, as shown by line labeled "Ksp". Addition or subtraction of phases with $\mathrm{K}: \mathrm{Si}$ of $\mathbf{O}$ will have a slope of zero, as indicated by the line labeled "Qtz, Plg." Symbols as in Figure 2. Data for intrusive and extrusive groups fall approximately on a common line with slope $0.2 \pm 0.09(2 \sigma)$; this line has a nonzero intercept at a $90 \%$ confidence level [see Nichols, 1988] an $r^{2}$ of 0.81 , and is significant (nonzero) above the $99 \%$ confidence level. Data for the three potassium-poor samples define a line of slope $0.9 \pm 0.7(2 \sigma)$; the $r^{2}$ of 0.98 is significant at the $95 \%$ confidence level, although the regression itself is significant only at the $90 \%$ confidence level. The 3K/Si ratio of the experiments of Vielze uf and Holloway [1988] (and hence the slope on the Pearce type diagram used here) for the $\mathrm{SiO}_{2}$ range sampled by the Ulugh Muztagh rocks averages $0.203 \pm$ 0.003 , and falls to a value of 0.134 at an $\mathrm{SiO}_{2}$ of $66 \mathrm{wt} \%$. Thus the slope of the intrusive and extrusive line in this projection is consistent with derivation by melting of a pelitic source. The $3 \mathrm{~K} / \mathrm{Si}$ ratio for a granite minimum melt is 0.24 , which is greater than that derived from the Ulugh Muztagh at greater than a 95\% confidence interval. The slope of the trend line for the potassium-poor samples, although subject to great uncertainty, is consistent with the unit slope of the trend line expected if removal of $\mathbf{K}$-feldspar from the system was the dominant mechanism for chemical differentiation.

defined by addition of $\mathrm{K}$-feldspar (as well as biotite or muscovite) has a slope of unity, while the slope for quartz and plagioclase is zero. Figure 8 clearly illustrates that the potassium-poor sample trend KSPO-QTL-UM10 could be produced simply by removal of K-feldspar (or mica) from a liquid. A simple least squares regression of this trend gives a slope of $0.9 \pm 0.7(2 s)$ and while the uncertainties are clearly enormous, additional information is available to support this conclusion.

A more detailed examination can be carried out through mass balance calculations. Whole rock contents of $\mathrm{SiO}_{2}$, $\mathrm{Al}_{2} \mathrm{O}_{3}, \mathrm{CaO}, \mathrm{Na}_{2} \mathrm{O}$ and $\mathrm{K}_{2} \mathrm{O}$ in QTL and UM10 were altered by addition of orthoclase (Or) and quartz $(\mathrm{Qz})$ to give the best fit to the KSPO compositions. Results and assumptions are given in Table 5. KSPO can be manufactured from mixtures of $0.81 \mathrm{QTL}+0.120 \mathrm{r}+0.07 \mathrm{Qtz}$ and $0.8 \mathrm{UM} 10+0.130 \mathrm{r}+0.07 \mathrm{Qtz}$ (weight fraction). These models have high, but not terribly high $\chi^{2}$ of 36 and 16.3, respectively, with two degrees of freedom. In both cases the largest residuals are in $\mathrm{Al}_{2} \mathrm{O}_{3}, \mathrm{CaO}$ and $\mathrm{Na}_{2} \mathrm{O}$, due perhaps to removal of a plagioclase component from the QTL or UM10 liquid. This hypothesis was not tested because the resulting model would have been overdetermined.

These mass balance calculations require the subtraction of 12 and 13 wt \% K-feldspar from KSPO to produce the composition of QTL and UM10, respectively. Such a dramatic change in bulk composition should be accompanied by a parallel change in the concentration of trace elements; those compatible with K-feldspar should be greatly depleted in QTL and UM10 in comparison to KSPO. This hypothesis could be tested directly by analysis of $\mathrm{K}$-feldspar and plagioclase separates for these samples, but because these data are currently lacking we use a more qualitative approach of comparing whole rock $\mathrm{Rb}$ and $\mathrm{Sr}$ contents to changes in total normative weight percent $\mathrm{K}$-feldspar and plagioclase between UM10 and QTL, as normalized relative to KSPO. Because $\mathrm{Rb}$ and $\mathrm{Sr}$ are, relative to one another, strongly partitioned into K-feldspar and plagioclase, respectively [Nash and Craecraft, 1985], and other phases in the rocks (quartz and minor tourmaline) have small masses of these elements, a large fraction of the whole rock $\mathrm{Rb}$ and $\mathrm{Sr}$ should reside in the $K$-feldspar and plagioclase phases, respectively. This comparison is shown in Table 5 and the results, though very qualitative, support the hypothesis that the chemical evolution of the potassium-poor rocks was controlled by removal of K-feldspar. Changes in $\mathrm{Rb}$ contents in QTL and UM10 measured relative to KSPO are very similar to the relative $\mathrm{K}$-feldspar contents, while the change in relative Sr contents, though a factor of 2 greater than the relative plagioclase increase, show the same sense of change. We conclude that removal of $\mathrm{K}$-feldspar and quartz from an initial melt was the dominant mechanism of formation for the potassium-poor samples, even though we are not able to offer a testable hypothesis to explain the mechanism by which this removal occurred.

Other scenarios for the production of the potassium-poor samples could include late weathering of an initially potassium-rich rock or alteration of an initially potassiumrich rock by metasomatic fluids. The trends in Figure 8 argues against the metasomatism model: such alteration would have had to remove not only potassium, but also Al and $\mathrm{Si}$ in the ratio expected for K-feldspar, an unlikely happenstance. Furthermore, there is little petrographic evidence of plagioclase replacement of K-feldspar in samples UM10 and QTL. Although late stage weathering of the potassium-poor samples could explain the odd $\mathrm{Pb} / \mathrm{U}$ ratio in these samples (see below), these samples were among the freshest we analyzed, and no petrographic evidence for alteration is present in the samples.

Samples QTL and UM10 have very high ${ }^{206} \mathrm{~Pb} /{ }^{204} \mathrm{~Pb}$ ratios, but ${ }^{207} \mathrm{~Pb} /{ }^{204} \mathrm{~Pb}$ and ${ }^{208} \mathrm{~Pb} /{ }^{204} \mathrm{~Pb}$ that are only slightly higher than those of sample KSPO. The $\mathrm{Pb}$ ratios of the latter sample are approximately equal to those of the intrusive and extrusive samples collected from Ulugh Muztagh. Part of the discrepancy in ${ }^{206} \mathrm{~Pb} / 204 \mathrm{~Pb}$ ratios within the potassium-poor samples is due to postcrystallization decay of ${ }^{238} \mathrm{U}$ in samples UM10 and QTL, which have extremely low $\mathrm{Pb}$ contents (less than 2 ppm for both). Unfortunately, the Pb analyses for UM10 and QTL are not sufficiently accurate to allow correction for this decay, and thus their initial lead isotope ratios are not 
TABLE 5. Mass Balance Constraints on the Formation of the Potassium Poor Samples

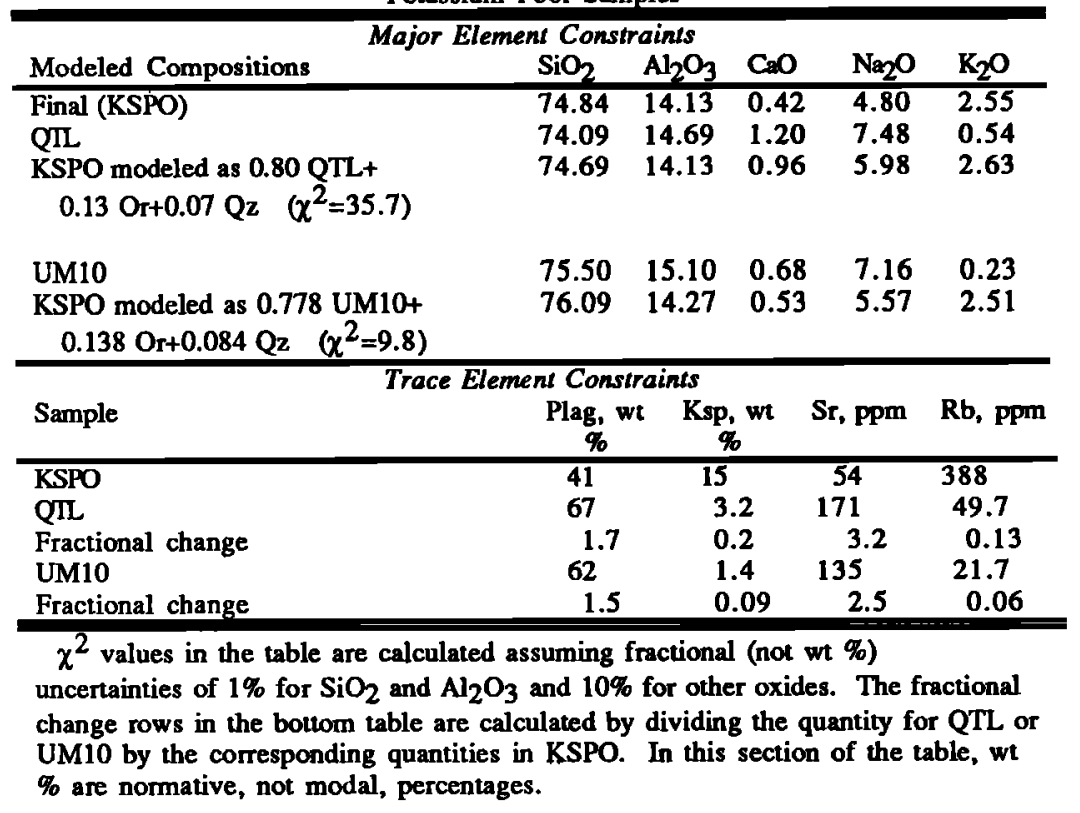

well constrained. If, as suggested above, KSPO, QTL and UM10 are comagmatic, than the $\mathrm{Pb}$ isotope ratios for KSPO, which has not changed significantly since crystallization, should give the initial ratio for all three potassium-poor samples: this sample plots within the Pelagic Sediment field in Figure 7, although it does appear to be distinct from the intrusive and extrusive samples. The ${ }^{87} \mathrm{Sr}^{86} \mathrm{Sr}_{\mathrm{i}}$ for samples QTL and UM10 is approximately equal to their measured ratios due to the low $\mathrm{Rb} / \mathrm{Sr}$ ratio of the rocks, the samples average $0.7118(1)$. This ratio plots well within the "crustally derived" field of Faure [1986], suggesting that these magmas were derived from a source with crustal composition.

\section{In Situ Melting of Source Rocks}

A necessary (although not sufficient) requirement for a crustal source for the Ulugh Muztagh magmas is that the P-T$X$ conditions within the crust were sufficient to produce a partial melt. A number of mechanisms have been proposed for in situ melting of crustal rocks, including frictional heating along thrust faults [LeFort, 1975]; melting of rocks in the hanging wall of thrust faults by release of fluids from footwall rocks ("flux melting") [LeFort, 1981]; and in situ radioactive decay and mantle heating in thickened continental crust [Molnar et al., 1983]. The amount of melt produced by "flux melting" is probably minor without the input of additional heat and is not considered further here. Shear heating, while capable of producing large quantities of heat obviously requires the existence of a fault in the source area, and while some Chinese workers have suggested thrust faults of Cenozoic age with large displacements may underlie the Ulugh Muztagh region (B. C. Burchfiel, personal communication, 1988), little detailed information is available to constrain heat production by this mechanism.

Heat production in the Ulugh Muztagh source region from in situ radioactive decay can be estimated from the radionuclide concentration in the extrusive rocks, and their estimated degrees of partial melting, $F_{v}$. Assuming bulk distribution coefficients for Th and $U$ of 0 during melting, an $F_{v}$ of 0.2 to $0.6, \mathrm{~K}_{2} \mathrm{O}$ concentration in the source of 4-5 wt $\%$, and a source density of $2.8 \times 10^{3} \mathrm{~kg} / \mathrm{m}^{3}$, the calculated heat production in the source would range from 1.7 to 4.6

TABLE 6. Source-Rock Concentrations

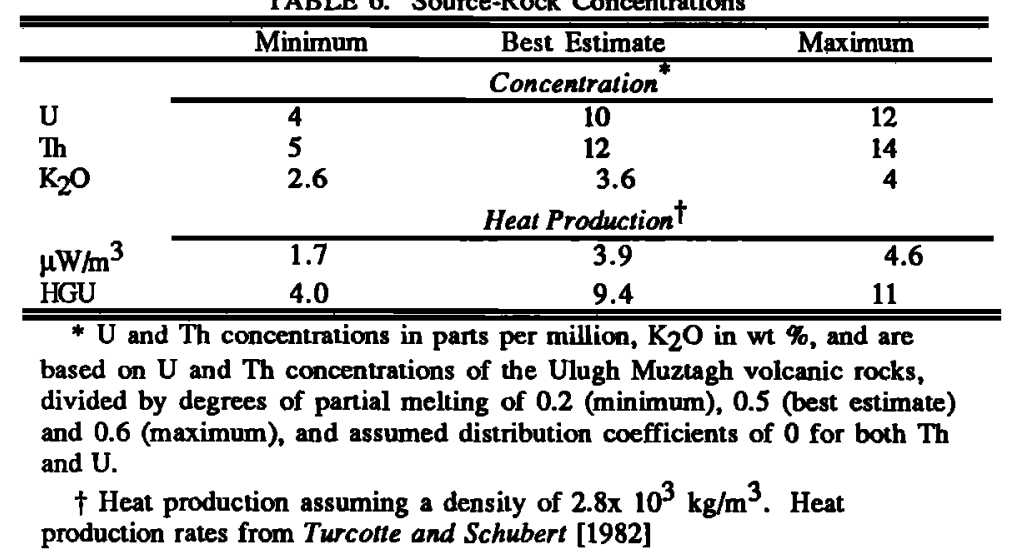


$\mu \mathrm{W} / \mathrm{m}^{3}$. Details of the calculations are given in Table 6 . While these rates of heat production are higher than those generally quoted for leucogranite source areas [e.g., Pinet and Jaupart, 1987], these estimates represent conservative limits for the Ulugh Muztagh source region: while decreasing $F_{v}$ would cause a linear decrease in the heat production rate, increasing the density of the source or the distribution coefficients for $T h$ and $U$ would increase heat production within the source. The presence of stable zircon in the restite would tend to increase the apparent partition coefficient of $U$ in the system, and the model described above would then underestimate the source $U$ concentration, and hence the source heat production. The inferred Th and $\mathrm{K}_{2} \mathrm{O}$ contents of the source region are similar to that of average shales, while our "best estimate" for the U concentration is approximately 3 times that in the average post-Archean shale [Taylor and McClennan, 1985].

The effects of these heat production rates on crustal temperatures can be inferred from the study of Molnar et al. [1983]. With slight modification of their results, this study can be used to determine the thermal perturbations of thin horizons of uraniferous rocks. Thermal effects of discrete horizons of radioactive material can be calculated from the shear heating calculations of Molnar et al, exchanging the product $A_{0} D$ (heat productivity from radioactive decay times layer thickness) for $\sigma v$ (resolved shear stress times velocity). While these substitutions appear ad hoc, both are suggested by Molnar et al. [1983].

Temperature perturbations due to in situ radioactive decay $\left(\Delta T_{r}\right)$ in isolated horizons, using the parameters of Table 7 , are functions of both the thickness and volumetric heat production within the layer. For heat production rates in Table 6, and a radiogenic layer $10 \mathrm{~km}$ thick, $\Delta T_{r}$ within this horizon range from 100 to $250 \mathrm{~K}$ some $20 \mathrm{Ma}$ after the layer was created. These $\Delta T_{r}$ estimates are of course very sensitive to the assumed parameters; the uncertainty in $k$ (thermal conductivity, here assumed to be $2.1 \mathrm{~W} / \mathrm{m}-\mathrm{K}$ [Pinet and Jaupart, 1987] is particularly large. Increasing $k$ will lead to lower $\Delta T_{r}$ because the heat will be transported from the source at a greater rate. Nonetheless, this procedure demonstrates that in situ radioactive decay may have contributed significant quantities of heat to the source region for the Ulugh Muztagh intrusive and extrusive rocks, leading to temperature increases of 70 to perhaps $200 \mathrm{~K}$. These thermal perturbations can be maintained for long time scales, due to the long half-lives of the radionuclides. Withdrawal of the radioactive nuclides by partial melting, such as invoked for the intrusive and extrusive rocks, would reduce (to zero, with the assumptions above) the concentration of the radionuclides, effectively halting the temperature increase by this mechanism. For nonzero apparent partition coefficients, residual $U$ and $T h$ would remain in the source and could continue to heat the restite.

The pressure-temperature-composition conditions necessary to produce partial melts in pelitic rocks to form magmas of granitic composition have been discussed by a number of authors [Hyndman, 1981; Thompson, 1982; Vielzeuf and Holloway, 1988]. Figure 9 illustrates the approximate $P-T$ loci of water present and water absent liquidii for pelitic compositions, along with granite solidii and approximate steady state geotherms for the Ulugh Muztagh region. Minimum temperatures necessary to produce partial melts are $-920 \mathrm{~K}$ if the system is saturated with extemally derived water and $1120 \mathrm{~K}$ for the more likely scenario of "fluidabsent melting" of a system wherein all fluid is supplied by dehydration of hydrous phases such as muscovite and biotite [Thompson, 1982; Vielzeuf and Holloway, 1988]. The steady state geotherms shown in the diagram are constrained by (1) the crustal thickness of $65 \pm 5 \mathrm{~km}$ [Molnar, 1988], (2) $\mathrm{T}_{\text {Moho }} \leq 1300 \mathrm{~K}$ [Molnar, 1988], and (3) nominal crustal heat production rates of $0-1 \times 10^{-6} \mathrm{~W} / \mathrm{m}^{3}$. This illustration demonstrates that temperatures necessary to partially melt pelitic rocks can be attained within the thickened crust of the Tibetan Plateau, with a wide variety of plausible heat sources.

For the minimum geotherm modeled, where the assumption of no heat production within the crust has been made, the geotherm intersects the dry liquidus at $\sim 1100 \mathrm{~K}$ and $70 \mathrm{~km}$ depth; addition of heat by in situ decay of radioactive nuclei $(100-200 \mathrm{~K})$ produces local intersection of the liquidus at temperatures and depths of less than $1050 \mathrm{~K}$ and $40 \mathrm{~km}$. A geotherm determined with an average volumetric heat production rate of $1 \times 10^{-6} \mathrm{~W} / \mathrm{m}^{3}$ in the top $30 \mathrm{~km}$ of crust intersects the dry liquidus at $1000 \mathrm{~K}$ and $\sim 30 \mathrm{~km}$ depth;

TABLE 7. Temperature Perturbations

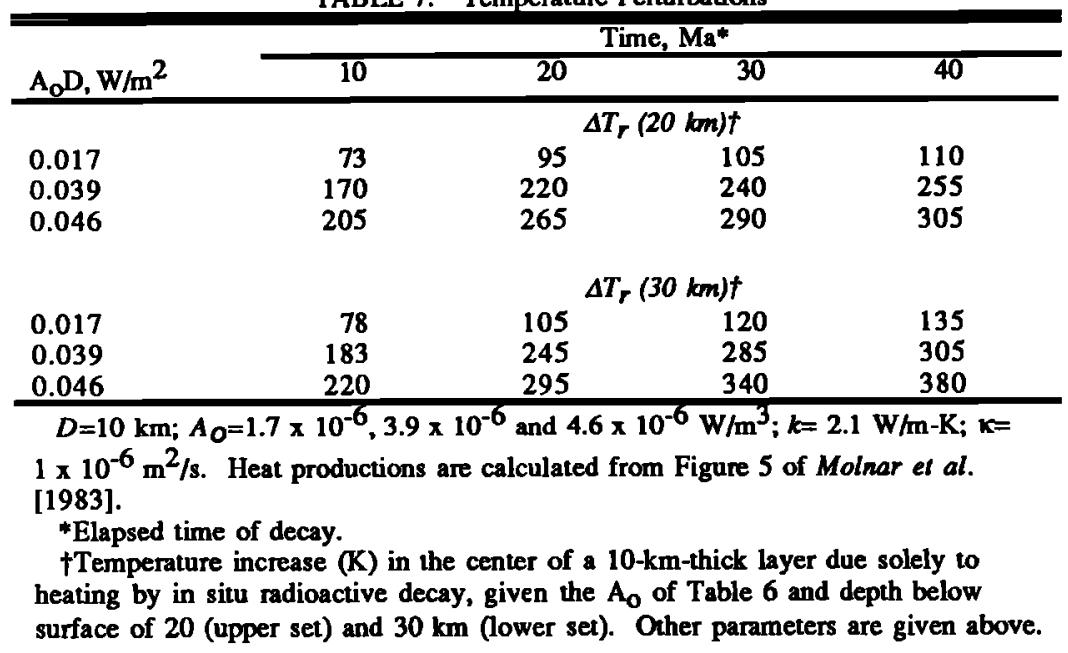




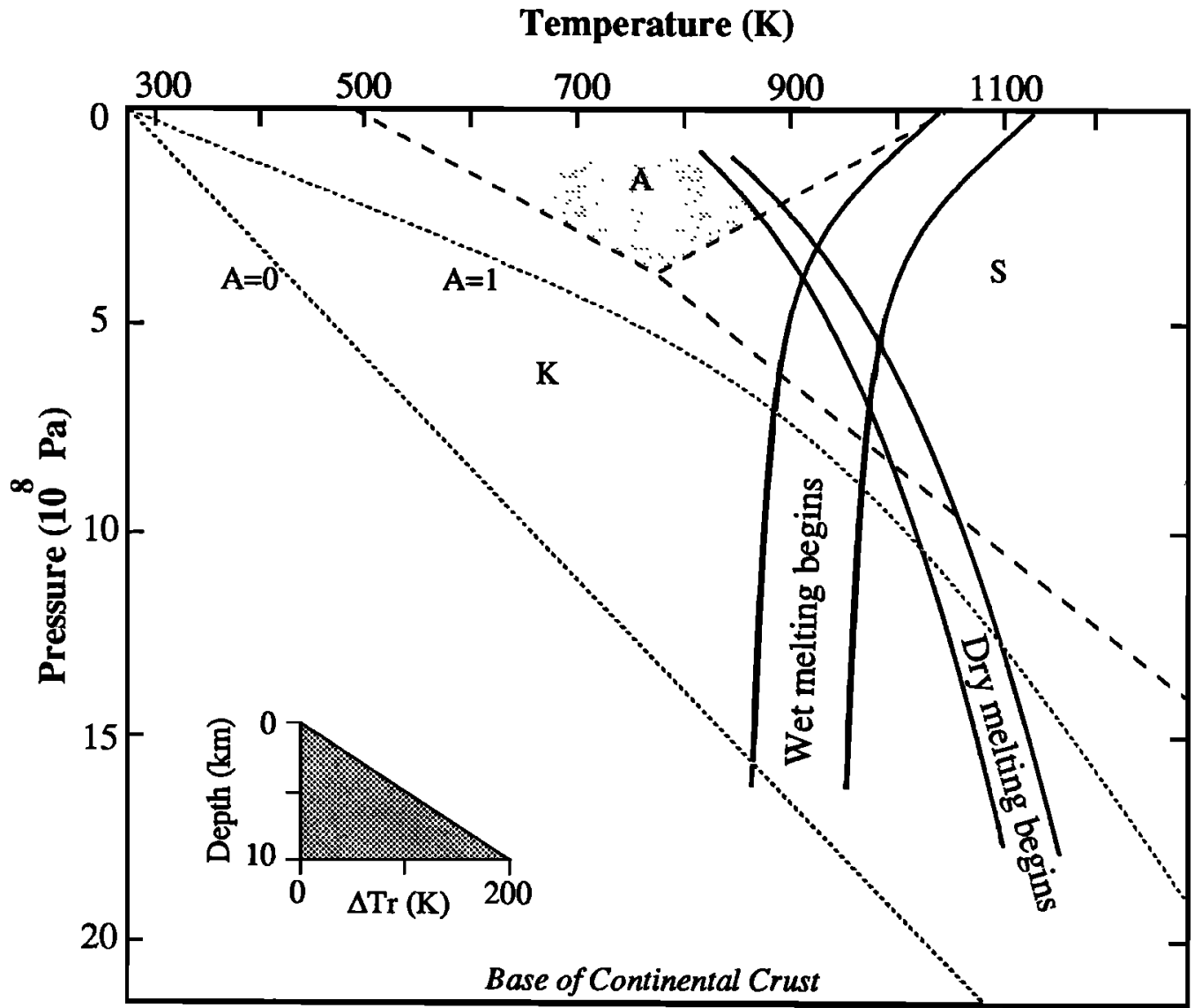

Fig. 9. Summary diagram of the themal structure of the Tibetan Plateau and depth-temperature relations of pelitic and granitic liquidii, adapted in part from Hyndman [1981], Thompson [1982] and Vielzeuf and Holloway [1988]. Temperature is given in Kelvin and pressure in $10^{8} \mathrm{~Pa}$ (=kbar). Thinner lines show location of aluminosilicate stability fields ( $A=$ andalusite, $K=k y$ anite, $S=$ sillimanite). Steadystate geotherms were constructed using current crustal thicknesses $(65 \pm 5 \mathrm{~km})$ and Moho temperatures $(\leq 1300 \mathrm{~K})$ [Molnar, 1988], and nominal heat production of 0 and $1 \times 10^{-6} \mathrm{~W} / \mathrm{m}^{3}$ (straight and curved lines labeled $A=0$ and $A=1$, respectively). Large, shaded triangle illustrates likely temperature increases in source region of Ulugh Muztagh magmas due to in situ radioactive decay (see Tables 7 and 8). The temperature increase is a function of the thickness of the source layer; this increase is given, at a specific thickness indicated by the vertical limb of the triangle by the distance from the vertical limb to the hypotaneuse of the triangle. Dry and wet melting zones indicate the $\boldsymbol{P}$-T locii of water saturated and water absent melting of pelitic source areas [Vielzeuf and Holloway, 1988]. Likely $P-T$ field for emplacement of the Ulugh Muztagh intrusive rocks is stippled.

addition of heat from in situ decay allows temperatures in excess of $1200 \mathrm{~K}$ at depths as shallow as $\sim 20 \mathrm{~km}$. These calculations show that superposition of reasonable geotherms for the Tibetan Plateau and temperature perturbations from radioactive decay can produce the temperatures necessary to partially melt even dry pelitic source rocks and to produce large volumes of melt. The upper temperature limits derived in Figure 9 are compatible with the temperature range of the experiments of Vielzeuf and Holloway [1988], demonstrating that the pressuretemperature-composition relationships within the source area for the Ulugh Muztagh intrusive and extrusive rocks are sufficient to produce an in situ partial melt.

\section{REGIONAL RELATIONSHIPS AND TECTONIC IMPLICATIONS}

The recent magmatism in the Ulugh Muztagh area is a part of a regionally extensive province of post-Middle Miocene vulcanism, which covers an elliptical area at least $300 \mathrm{~km}$ in extent north-south and $600 \mathrm{~km}$ east-west within the north- central Tibetan Plateau. The approximate age and type of volcanism is shown in detail in Figure 10, adapted from the Geological Map of the Tibetan Plateau [Ministry of Geology and Natural Resources, 1980]. Two features of interest in this map are the latitudinal zonation of the chemistry of the volcanics and the sharp, linear northem and eastern edges of the province. This northern front strikes obliquely relative to the edge of the plateau (as represented by the trace of the Altyn Tagh Fault), but is subparallel to, and 100-50 km north of, the trace of the Jinsha Suture. Ulugh Muztagh is found along the western section of the northern edge of the province.

Deng [1978] reported the results of a reconnaissance field trip, detailed optical petrography, and major element chemistry of Quatemary volcanic rocks exposed south of Ulugh Muztagh. He separated these flows into three groups: the southern Bamogiongzong, central Yongbohu and the northern Qiangbaqian sequences. As shown in Figure 10, these units lie 200,100 , and $50 \mathrm{~km}$, respectively, south of 


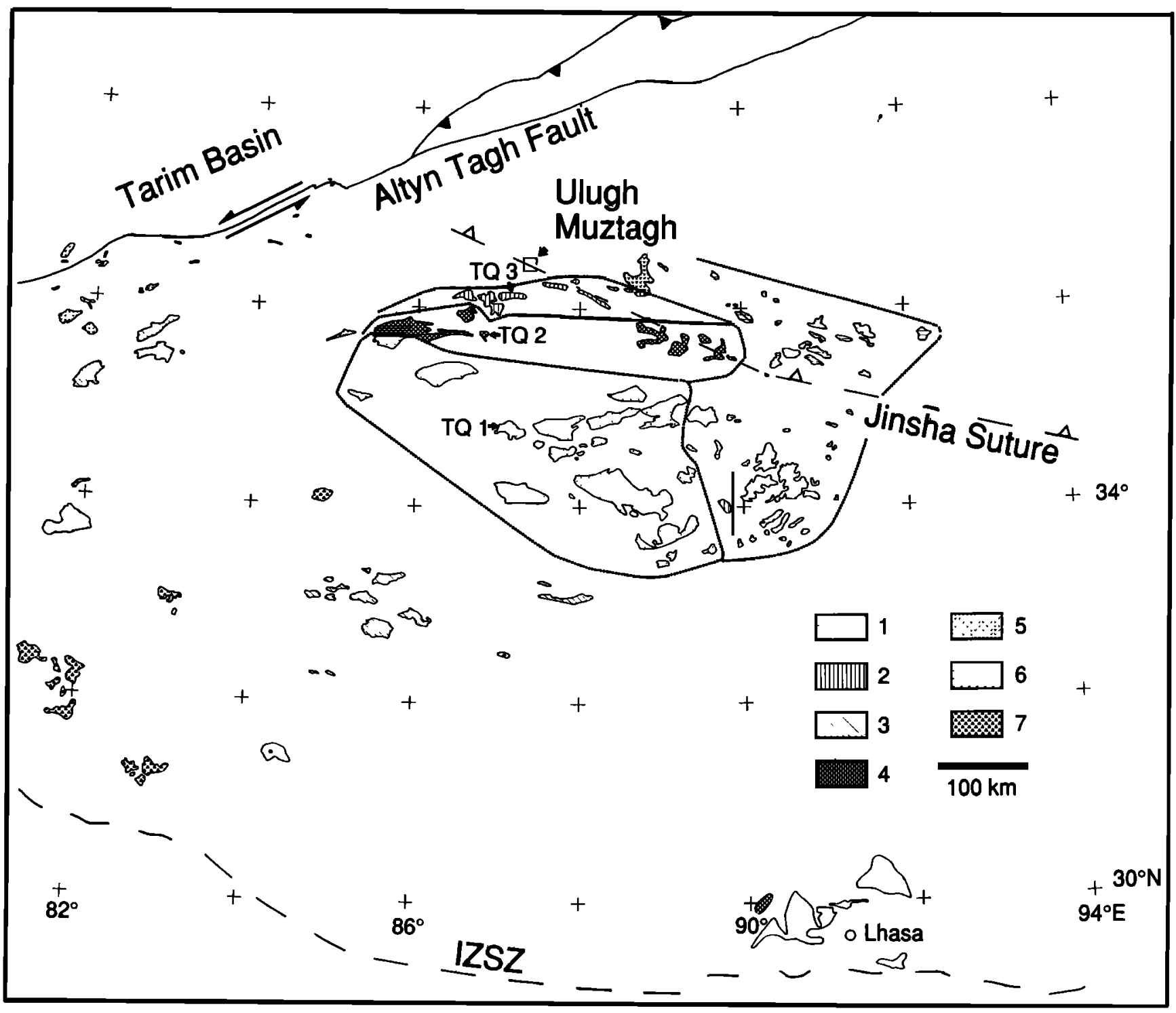

Fig. 10. Simplified geologic map of post-Early Miocene volcanic rocks on the Tibetan Plateau, modified and adapted from The Geologic Map of the Tibetan Plateau [Ministry of Geology and Natural Resources, 1980] and [Coulon et al., 1986]. Rock types and approximate ages are shown by shading: 1, Neogene andesitic volcanic rocks; 2 , Pliocene to Recent andesitic volcanic rocks; 3 , undifferentiated andesitic volcanic rocks; 4, potassic Pliocene to Recent andesitic volcanic rocks; 5 . Pliocene to Recent basic volcanic rocks; 6, potassic Pliocene to Recent basic volcanic rocks; 7, undifferentiated basic volcanic rocks. Unshaded areas are older, undifferentinted volcanic rocks. The central Tibetan Plateau volcanic field is shown in the center of the figure, dotted lines separate areas of distinct rock type. The Altyn Tagh Fault forms the northem structural and topographic front of the Plateau; note the angular discordance between this structure and the B-W trending northern boundary of the volcanic province and compositional subprovinces. Following Molnar, [1988], observe that the volcanic province is located over an area of anomalously hot upper mantle; it appears from the data of Deng, [1978]; and Pearce and Mei, [1988] that units 5, 6, and 7 are formed by partial melting of enriched mantle. The band of unit 2 (which includes sample TQ 3 ) between Ulugh Muzzagh and TQ 2 represent hybrid magmas formed through mixing of crustally derived mantle melts similar to those exposed at Ulugh Muzagh and mantle melts similar to those exposed at TQ 2 . Fault
ornamentation as in Figure 1 .

the volcanic units exposed at Ulugh Muztagh and lie on the northem section of the Qiangtang terrain. The southern sequence includes ultrapotassic rocks varying from tephrite basanites to phonolites. Typical phenocrysts include leucite, analcite, nephiline, nosean, olivine (Fo75) and aegerine-augite. The central sequence are transitional to calc-alkaline tephrite basanites to trachyandesites and dacites, while the northern group are typically calc-alkaline trachydacites to subalkalic rhyolites [Deng, 1978; Pearce and $M e i, 1988]$. The age of all of these units was suggested by Deng [1978] to be Quaternary, based on relationships with underlying rocks of assumed Plio-Pleistocene age. The silica and potash concentrations of these samples agree reasonably well with the compositions expected from their unit identification on the Geological Map of the Tibetan Plateau. In that map's terminology, and in the terminology followed 
in Figure 10, samples TQ1, 2 and 3 are ultrapotassic basic rocks (unit 6 in Figure 10), ultrapotassic andesitic rocks (unit 4), and intermediate rocks (unit 2), respectively. The variation in rock type recorded by Deng [1978] in the Yongbohu volcanics may indicate that the central unit 4 province in Figure 10 includes a range of lithologies from basanite to andesite.

One sample from each of the sequences identified by Deng [1978] was re-analyzed by Pearce and Mei [1988]. As noted by Pearce and Mei [1988], the TQ samples all show extraordinary enrichment of the REEs and the LIL elements $(\mathrm{Rb}, \mathrm{Sr}, \mathrm{Th})$ indicative of derivation from a highly enriched source area, due perhaps to assimilation of a subduction component [Pearce and Mei, 1988]. Despite this enrichment, all three samples demonstrate a consistent high field strength elements depletion [Salters and Shimizu, 1988], a characteristic not atypical of subcontinental lithosphere. The high $\mathrm{MgO}$ contents and $\mathrm{Mg}$ numbers for the basanite indicate that these magmas are direct mantle melts, apparently extruded through the $65 \mathrm{~km}$ thickness of the plateau.

Based on the available major and trace element data for the TQ rocks, we suggest that the volcanic rocks exposed in and south of Ulugh Muztagh are related by magma mixing: the end-members are represented by the high silica crustal melts exposed at Ulugh Muztagh and the basanite samples of the central Yongbohu province south of Ulugh Muztagh (Figure 11). Mass balance calculations indicate that the analyzed sample from the northem Qiangbaqian sequence (sample TQ 3) formed from approximately equal fractions of the two endmembers. The major element chemistry of the Bamogiongzong sequence, as represented by sample TQ 1 of Pearce and Mei [1988], apparently formed by fractional crystallization of hybrid melts.
While we recognize the potential danger of drawing conclusions from such a small data set, the Geological Map of the Tibetan Plateau suggests that the patterns seen in the data discussed here may well be representative of patterns in the central volcanic province as a whole, and are certainly testable when additional data become available. These results are compatible with a model for Pleistocene-Recent magmatism along the northem Qiangtang terrain which is dominated by mixing of two end-member compositions. The silica rich end-member (represented by the Ulugh Muztagh extrusives) forms through in situ partial melting of pelitic rocks within the thickened Tibetan crust. The mafic endmember (represented by the TQ 2, the Yongbohu sequence) forms through partial melting of enriched, perhaps metasomatized subcontinental mantle, and occurs, as shown in Figure 10, in a band $50 \mathrm{~km}$ thick between the southern ultrapotassic and the northern hybrid provinces. These endmembers occur approximately $100 \mathrm{~km}$ apart, while the hybrid magma lies $50 \mathrm{~km}$ south of Ulugh Muztagh. Most likely, neither of the chemical end-members are point sources; we do not envision veins of magma stretching 50 $\mathrm{km}$ to $\mathrm{mix}$ together in the central belt. Rather, we hypothesize that partial melting of the crust, and hence production of the silicic end-member, occurs laterally throughout the crust. To the north, unadulterated crustal melts reach the surface owing to a lack of mantle melt, while in the Qiangbaqian area, subequal volumes of the end members are present. In the Yongbohu area, an entire suite of basanite to rhyolite indicates the presence of both hybrid liquids and unadulterated mantle melts. Finally, south of the Yongbohu belt, a wide area of ultra-potassic rocks represents an area of hybrid liquids strongly modified by low-pressure fractionation, as suggested by sample TQ 1 .

A number of studies (see Molnar [1988] for a review) have

\section{Tibetan Plateau}

Tarim Basin

TQ2 UM

TQ1 TQ3

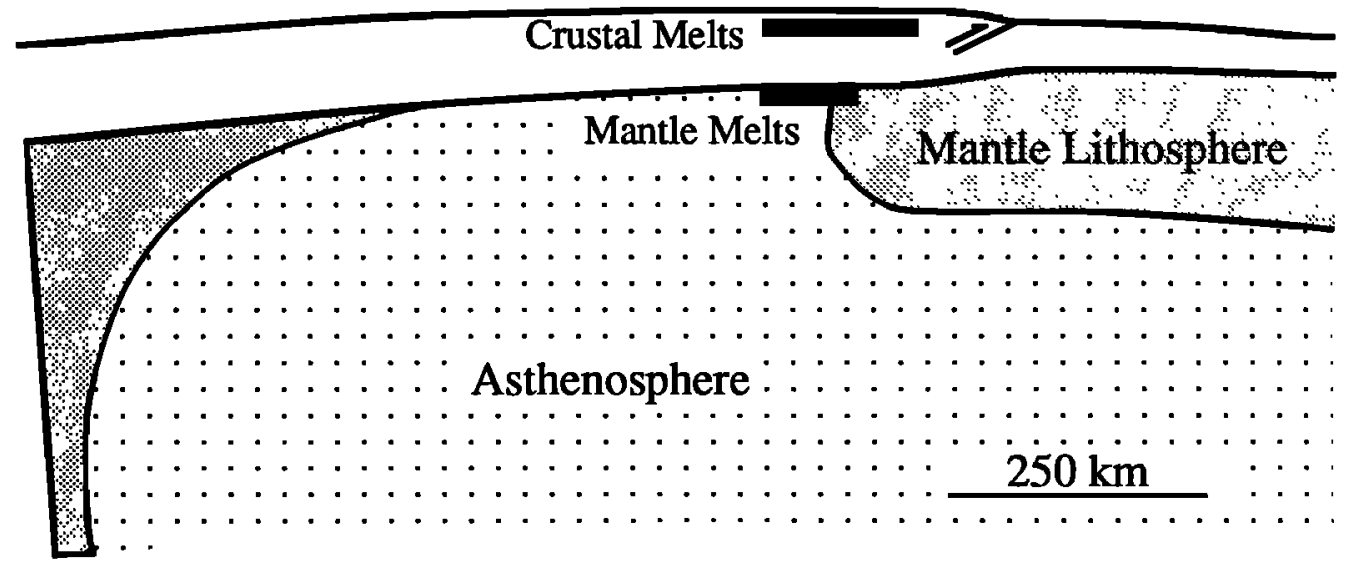

Fig. 11. A sketch of the sources and mixing areas of magmas in the central Tibetan province, modified from Molnar, [1988]. The areas of mantle upwelling are shown by arrows; approximate locations of Ulugh Muztagh, TQ 3 and TQ 2 are also shown. Silicic magmas are produced through crustal melting of pelitic or perhaps amphibolitic material over a wide region of the plateau ( $\mathrm{N}$-dipping hatching), while mantle-derived melts occur only south of the area of active upwelling (S-dipping hatching). The resulting hybrid magmas can cover wide areas of the central plateau, but the northem terminus of the mafic magmas should indicate the northem terminus of the upwelling. If so, data for the Ulugh Muztagh extrusive rocks indicate the length of the boundary between eroded and uneroded lithosphere is of the order of $100 \mathrm{~km}$. 
demonstrated the existence of a high impedance zone in the upper mantle below the north-central Tibetan Plateau, the same area occupied by the volcanic province. Molnar [1988] hypothesized that this anomaly was due to the presence of relatively hot, perhaps partially melted, mantle material driven convectively against the base of the Tibetan continental lithosphere. This thinning of the mantle lithosphere beneath the central Plateau has produced the lateral thermal gradients resolved by teleseismic studies. Molnar also suggested that the approximate correspondence of the volcanic province with the thermal anomaly was evidence of a causal relationship.

The large-scale mixing observed in the volcanic rocks south of Ulugh Muztagh confirms this model and allows some detail to be added to it. The geochemical gradient between the central Yongbohu sequence and the crustally derived melts is caused by the thermal gradient imposed by mantle convection. The mantle-derived melts form south of the line at which hot, superadiabatic material is juxtaposed with continental lithosphere. North of this line, mantle temperatures are too low, or lithospheric thicknesses too high, to allow formation of melts or their transport to the surface. If true, the distribution of volcanic rocks on the plateau suggest that the width of the thinned zone of asthenosphere is approximately equal to the width of the mixing area defined by the Ulugh Muztagh and Yongbohu sequences, or approximately $100 \mathrm{~km}$. This would require significant lateral thermal and mechanical gradients in the mantle below the plateau.

If the northward limit of Cenozoic volcanism does follow subcrustal thermal anomalies, the angular discordance between this anomaly and the topographic and structural front of the Tibetan Plateau has important implications. The topographic relief (from the westemmost exposure to the easternmost exposure of mafic melts, see Figure 10) along the northern limit of volcanism is over $2 \mathrm{~km}$. If the northern terminus of the mafic rocks maps the thermal anomaly within the mantle, the subcrustal thermal structure is clearly not affecting the formation of the plateau. In other words, the mantle-crust system in central Asia appears to be decoupled, with the mechanisms of crustal thickening operating independently, but synchronously, with the mechanisms affecting the mantle. If a link between the mantle thermal structure and the creation and maintenance of the plateau's elevation does exists, it appears to be operating on time scales longer than that recorded in the upper Cenozoic volcanic rocks present in the central plateau that are examined here.

The time scale and rate of thickening in this part of the plateau can be estimated from the ${ }^{40} \mathrm{Ar} /{ }^{39} \mathrm{Ar}$ geochronology results of Burchfiel et al. [1989], along with the estimate for maximum depth of emplacement for the intrusive rocks (4 $\mathrm{x}$ $10^{8} \mathrm{~Pa}$, or approximately $10-12 \mathrm{~km}$ ). The minimum age of crystallization for the intrusive rocks is provided by the 10.5 Ma muscovite plateau age for UBTG; the $\mathrm{Sr}$ isotopic data presented above suggest possible crystallization ages of 11-12 Ma. The intrusive suite was exposed at the surface by 4.0 $\mathrm{Ma}$, as the well-dated extrusive rocks overlie a boulder conglomerate which contains abundant clasts of the intrusive rocks. Thus the maximum average unroofing rate between 10-12 $\mathrm{Ma}$ and $4 \mathrm{Ma}$ is $10-12 \mathrm{~km} / 6-8 \mathrm{Ma}=1.25-2 \mathrm{~mm} / \mathrm{a}$. The actual unroofing rate may well have exceeded this average rate for short time intervals; our estimate merely states that the time-integrated unroofing rate for the Ulugh Muztagh region is less than $1.25-2 \mathrm{~mm} / \mathrm{yr}$. Interestingly, Molnar et al. [1987] estimated that thrust faults along the northem edge of the Tibetan Plateau have vertical slip rates of 1-2 $\mathrm{mm} / \mathrm{yr}$, in good agreement with the crustal thickening rates estimated by examination of the Ulugh Muztagh igneous rocks.

\section{ConClusions}

The granites, granodiorites, rhyolites, and trondhjemites collected from the Ulugh Muztagh region of the northern Tibetan Plateau are leucocratic, potassic, primarily peraluminous rocks which formed from crustally derived partial melts. These melts were produced at depths of 20-40 $\mathrm{km}$ by heating of the source region through in situ radiogenic decay and mantle heat flux into thick, and hence insulative, continental crust. The igneous rocks currently exposed at Ulugh Muztagh form both extrusive and intrusive bodies; regional contact metamorphic relationships suggest that the intrusive rocks were emplaced at pressures less than $4 \times 10^{8} \mathrm{~Pa}$.

Burchfiel et al. [1989] have reported ${ }^{40} \mathrm{Ar} /{ }^{39} \mathrm{Ar}$ data that documents a minimum age difference between the intrusive and extrusive samples of 4-6.5 Ma. The younger rhyolitic extrusive rocks have major element abundances, trace element abundances, and ${ }^{87} \mathrm{Sr} /{ }^{86} \mathrm{Sr}$ and ${ }^{206} \mathrm{~Pb} /{ }^{204} \mathrm{~Pb}$ ratios similar to those of the intrusive rocks. Although the extrusives appear to be significantly younger than the intrusives, the chemical data suggest that both the extrusive and the intrusive rocks considered here were derived from the same, or very similar, source rocks of pelitic composition. This history of crustally derived magmatism requires maintenance or episodic attainment of super-solidus crustal temperature for time scales of 5 to 10 million years. The depth of emplacement of the intrusive rocks and the inferred depth of the source rocks suggests that rates of crustal thickening and unroofing in the north-central Tibetan Plateau may be approximately equal, at $1-2 \mathrm{~mm} / \mathrm{yr}$. These rates are similar to those estimated by Molnar et al. [1987] from ground level reconnaissance observations and suggest that the north central Tibetan Plateau may be in a steady state condition, with the rates of crustal thickening approximately equal to the rate of unroofing.

Consideration of the extrusive samples at Ulugh Muztagh and other Pliocene to recent volcanic rocks south of Ulugh Muztagh suggests that large-scale mixing of crustal melts and mantle derived melts is occurring in the north central Tibetan Plateau. The east-west trending compositional zones are due to similarly trending thermal gradients in the upper mantle below the plateau. The oblique angle between the subplateau thermal structure and the Tibetan Plateau itself indicates that the mechanisms of crustal thickening may operate independently of mechanisms controlling the thermal and mechanical structure of the mantle.

\section{APPENDIX 1}

MV2, UMVU and UM3V are rhyolitic tuffs characterized by glomerophyric plagioclase (An20-25) and sanidine, phenocrystic quartz (up to $7 \mathrm{~mm}$ dianeter) and biotite, and subhederal to anhederal cordierite in a microlitic groundmass. Cordierite is surrounded by a felty, colorless rim 10-30 $\mathrm{mm}$ thick, and locally has altered to pinite. Zircon included in cordierite crystals are anhederal, broken grains, with no mantles. Sanidine and biotite separates from MV2 
APPENDIX 2: REE Corrections From U Fission

\begin{tabular}{|c|c|c|c|c|c|c|c|c|c|c|c|c|c|}
\hline \multirow[b]{2}{*}{ Element } & \multicolumn{6}{|c|}{ Extrusives } & \multicolumn{4}{|c|}{ Intrusives } & \multicolumn{3}{|c|}{ Potassium-poor } \\
\hline & MV1B & UMIB & MV2 & UM3V & UMVU & UMQP & QID & BKSP & UBTG & 2MGR & KSPO & QIL & UM10 \\
\hline La & 1.03 & 1.03 & 0.72 & 0.69 & 0.63 & 0.47 & 0.33 & 0.57 & 0.46 & 0.3 & 0.54 & 0.25 & 0.27 \\
\hline$\sigma \mathrm{La}^{*}$ & 0.24 & 0.2 & 0.1 & 0.15 & 0.1 & 0.06 & 0.04 & 0.12 & 0.1 & 0.05 & 0.07 & 0.03 & 0.04 \\
\hline $\mathrm{Ce}$ & 7.02 & 7.02 & 4.91 & 4.7 & 4.27 & 3.19 & 2.24 & 3.89 & 3.13 & 2.08 & 3.67 & 1.73 & 1.86 \\
\hline$\sigma C e$ & 1.62 & 1.35 & 0.68 & 1.03 & 0.7 & 0.43 & 0.3 & 0.84 & 0.65 & 0.32 & 0.49 & 0.22 & 0.24 \\
\hline $\mathbf{N}$ & 5.46 & 5.46 & 3.82 & 3.65 & 3.32 & 2.48 & 1.74 & 3.02 & 2.44 & 1.62 & 2.86 & 1.34 & 1.45 \\
\hline$\sigma N d$ & 1.4 & 1.18 & 0.6 & 0.89 & 0.62 & 0.39 & 0.27 & 0.73 & 0.56 & 0.29 & 0.44 & 0.19 & 0.22 \\
\hline Sm & 0.1 & 0.1 & 0.07 & 0.07 & 0.06 & 0.05 & 0.03 & 0.06 & 0.05 & 0.03 & 0.05 & 0.03 & 0.03 \\
\hline$\sigma \mathrm{Sm}$ & 0.04 & 0.03 & 0.02 & 0.02 & 0.02 & 0.01 & 0.01 & 0.02 & 0.02 & 0.01 & 0.02 & 0.01 & 0.01 \\
\hline
\end{tabular}

Values in the table are the concentrations (in parts per million) of elements produced in the samples by induced $U$ fission /Korotev and Kindstrom, 1985]. These values were subtracted from the INAA results to give the true concentrations of the elements reported in Table 2.

* Fully propagated $2 s$ uncertainties in the corrections, in parts per million.

were analysed for ${ }^{39} \mathrm{Ar} /{ }^{40} \mathrm{Ar}$. The sanidine had a plateau age of 4.0 $\pm 0.1 \mathrm{Ma}(72 \%$ of gas in three steps, total gas age was $4.1 \mathrm{Ma})$, and biotite gave a total gas age of $4.2 \pm 0.1 \mathrm{Ma}$.

UMQP is a porpyritic rhyolite with quartz, sanidine, cordierite and biotite phenoctysts in a microlitic groundmass. Tourmaline is present in trace quantities, and although typically of small size is clearly a phenocrystic phase. The isotropic groundmass consists of 10-50 $\mu \mathrm{m}$ diameter quartz+plagioclase+sanidine (70\%), opaques (20\%) and biotite (10\%)

MV1B and UM1B are glassy rholitic flows with porphyritic to locally glomerophyric plagioclase and porphyrititc sanidine, quartz, cordierite and biotite in a glassy matrix. Plagioclase is locally fluid-inclusion rich, individual laths are up to $4-5 \mathrm{~mm}$ in length. Cordierite grains are typically smaller in size than the plagioclases, and some display overgrowths of cordierite around central, zoned grains. A sanidine separate from MV1B had a $4.0 \pm 0.1 \mathrm{Ma}$ ${ }^{39} \mathrm{Ar} / 40 \mathrm{Ar}$ plateau age (five steps, $100 \%$ of the gas).

BKSP and UBTG are coarse grained, panidiomorphic granites with phenocrysts of perthitic, poikolitic alkali feldspar and quartz with smaller phenocrysts of plagioclase $\left(A_{2} n_{25}-45\right)$ and biotite in a medium grained, equigranular groundmass of quartz, alkali feldspar and biotite. Zircon inclusions in biotite included clear to very dark colored grains all less than $50 \mathrm{~mm}$ long. Clear grains are euhederal and show no radiation haloes, dark grains are anhederal and are surrounded by radiation-darnage haloes. Three mineral separates were analyzed by ${ }^{39} \mathrm{Ar} /{ }^{40} \mathrm{Ar}$. Muscovites gave a $10.5 \pm 0.1 \mathrm{Ma}$ plateau (78\% of the gas in two steps), biotite a total gas age of $10.1 \pm 0.1$ $\mathrm{Ma}$ and sanidine displayed a minimum age of $9.1 \mathrm{Ma}$ with a total gas age of $10.2 \pm 0.1 \mathrm{Ma}$.

2MGR is a medium grained hypidiomorphic granular, two-micagranite. Quartz grains typically show undulatory extinction, muscovite locally shows very minor kinking. Mucovite has very few inclusions of any sort except for rare zircon, while biotites contain abundant (a few volume percent) opaque inclusions. Zircons occurs as both inclusions in other phases and as interstitial grains; in both environments the zircons are irregular, anhederal and optically cloudy. A biotite separate from this sample gave an ${ }^{39} \mathrm{Ar} /{ }^{40} \mathrm{Ar}$ age of $10.0 \pm 0.1 \mathrm{Ma}$ (total gas), while a potassium feldspar separate displayed a $9.8 \pm 0.1 \mathrm{Ma}$ total gas age with a minimum of 8.9 Ma.

QTD consists of medium grained, porphyrititc quartz, orthoclase and plagioclase in a fine grained, microlitic groundmass. Toumaline is present in trace quantities - these grains generally contain abundant inclusions of zircons. Locally poikiolititc sanidine grains are less than $5 \mathrm{~mm}$ in length and contain quartz and very rarely allanite inclusions. A potassium feldspar separate analysed by ${ }^{39} \mathrm{Ar} / 40 \mathrm{Ar}$ returned a total gas age of $8.4 \pm 0.1 \mathrm{Ma}$ with a minimum age of $8.1 \mathrm{Ma}$.

UM10 and QTL are unusual rocks. Both samples consist of phenocrystic quartz and plagioclase, typically $5-10 \mathrm{~mm}$ in length, in a fine grained microcrystaline groundmass. Minor tourmaline (schorl) occurs as pheocrystic laths less than 4-5 mm in length.
The isotropic groundmass consists of quartz and plagioclase with diameters less than $30-50 \mathrm{~mm}$. In UM10, faces of tourmaline and quartz are rough on the scale of $30-50 \mathrm{~mm}$, aparently due to reaction of the grains with the groundmass, while the faces of plagioclase grains are quite sharp. In QTL, the plagioclase grains display this rough texture, while the quartz and tourmaline faces are sharp. Trace quantities of zircon (cloudy, anhederal) are present within the tourmaline.

KSPO is a rather coarse grained granodiorite with phenocrysts of alkali feldspar (2-15mm in length), quartz and plagioclase with interstitial, fine-grained biotite and muscovite. Laths of allanite occur both as inclusions in other phases and as interstitial grains. In the former environment, the grains are stuby and anhederal, while the interstitial grains are long, thin, optically clear laths upto $500 \mu \mathrm{m}$ in length.

Acknowledgments. We would like to thank Drew Coleman for XRF preparation; S. R. Hart for the use of the Geoalchemy lab at MIT; W. R. Van Schmus and M. E. Bickford for consultation at the XRF and mass-spec facilities at the University of Kansas; and F. Frey for use of, and P. Ila for her help in all aspects of, the INAA facility at MIT. Ye Hongzhuan kindly translated map legends and tables for us: his assistance was crucial to our understanding of ideas presented here. Kevin Furlong wrote the program "Geotherm" used in producing Figure 9. B. Nelson and an anonymous reviewer provided excellent reviews of this manuscript; B. C. Burchfiel, P. Le Fort, K. Burke and V. Salters read early versions of the manuscript and suggested improvements to it. Although they may not necessairily agree with any of the ideas presented herein, we appreciate their efforts. The paper was typeset by Elizabeth Spizman. Financial support provided by the Student Research Fund Committee of the Department of Earth Atmospheric, and Planetary Sciences at MIT (L.W.M.), the National Science Foundation (EAR 8805125 to S. R. Hart, EAR 8517889 to W. R. Van Schmus) and the Shell Oil Company (J.D.W.).

\section{REFERENCES}

Anders, E., and M. Ebihara, Solar-system abundances of the elements, Geochim. Cosmochim. Acta, 46, 2363-2380, 1982.

Backstrom, H., and H. Johanssen, Geology, in Scientific Results of a Journey in Central Asia 1899-1902, edited by S. Hedin, Vol. 6, pt. 2, Stockholm, 1907.

Burchfiel, B. C., P. Molnar, Z. Zhao, K. Liang, S. Wang, M. Huang, and J. Sutter, Geology of the Ulugh Muztagh Area, Northern Tibet, Earth Planet. Sci. Lett., 94, 57-70, 1989.

Chang, C., et al., Preliminary conclusions of the Royal Society and Academia Sinica 1985 Geotraverse of Tibet, Nature, 323, 501507, 1986.

Coulon, C., H. Maluski, C. Bollinger, and S. Wang, Mesozoic and Cenozoic volcanic rocks from central and southern Tibet: ${ }^{39} \mathrm{Ar}$ ${ }^{40}$ Ar dating, petrological characteristics and geodynamical significance, Earth Planet. Sci. Lett., 79, 281-302, 1986. 
Deng. W., A preliminary study on the petrology and petrochemistry of the Quatemary volcanic rocks of northem Tibet autonomous region (in Chinese), Acta. Geol. Sinica, 52, 148-162, 1978.

Faure, G., Principles of Isotope Geology, 587, Pp., John Wiley, New York, 1986.

Harris, N. B. W., R. Xu, C. L. Lewis, and C. Jin, Plutonic rocks of the 1985 Tibet Geotraverse, Lhasa to Golmud, Philos. Trans. $R$. Soc. London Ser. A, 327, 145-168, 1988.

Hart, S. R., and C. Brooks, The geochemistry and evolution of early Precambrian mantle, Contrib. Mineral. Petrol., 61, 109-128, 1977.

Hyndman, D. W., Controls on source and depth of emplacement of granitic magmas, Geology, 9, 244-249, 1981.

$\mathrm{Ila}, \mathrm{P}$., and F. Frey, Utilization of neutron activation analysis in the study of geologic materials, Atomkernenerg. Kerntech., $44 \mathrm{~S}$, 710-716, 1984.

King, R. W., R. W. Kerrich, and R. Dadar, REE distributions in tourmaline: An INAA technique involving pretreatment by $B$ volatilization, Am. Mineral., 73, 424-431, 1988.

Korotev, R. L. and D. J. Lindstrom, Interferences from fission of 235U in INAA of rocks, Trans. Amer. Nuclear Soc., 49, 177-178, 1985.

Le Fort, P., Himalayas: The collided range, Present knowledge of the continental arc, Am. J. Sci., 275, 1-44, 1975.

Le Fort, P., Manaslu leucogranite: A collision signature of the Himalaya, A model for its genesis and emplacement, J. Geophys. Res., 86, 10545-10568, 1981.

Lindstrom, D. J., and R. L. Korotev, Teabags: Computer programs for instrumental neutron activation analysis, J. Radioanal. Chem., 70, 439-458, 1982.

Littledale, S. G. R., A journey across Tibet from north to south and west to Ladak, Geogr. J., 7, 453-465, 1886.

Miller, C., Are strongly peraluminous magmas derived from pelitic sedimentary sources?, J. Geol., 93, 673-689, 1985.

Ministry of Geology and Natural Resources, Geological map of the Qinghai-Xizang (Tibet) Plateau (1:1.5 Million scale), Ministry of Geology and Natural Resources, Beijing, 1980.

Molnar, P., A review of geophysical constraints on the deep structure of the Tibetan Plateau, the Himalaya, and the Karakorum and their tectonic implications, Philos. Trans. R. Soc. London, Ser. A, 326, 33-88, 1988.

Molnar, P., W.-P. Chen, and E. Padovani, Calculated temperatures in overthrust terrains and possible combinations of heat sources responsible for the tertiary granites in the greater Himalaya, $J$. Geophys. Res., 88, 6415-6429, 1983.

Molnar, P., B. C. Burchfiel, L. K'uangyi, and Z. Ziyun, Geomorphic evidence for active faulting in the Altyn Tagh and northern Tibet and qualitative estimates of its contribution to the convergence of India and Eurasia, Geology, 15, 249-253, 1987.

Nance, W. B., and S. R. Taylor, Rare Earth element pattems and crustal evolution, I, Australian post-Archean sedimentary rocks, Geochim. Cosmochim. Acta, 40, 1539-1551, 1976.

Nash, W. P., and H. R. Craecraft, Partition coefficients for trace elements in silicic magmas, Geochim. Cosmochim. Acta, 49, 2309-2322, 1985.

Nekvasil, H., Calculation of equilibrium crystallization paths of compositionally simple hydrous felsic melts, Am. Mineral., 73, 956-965, 1988.

Nichols, J., The statistics of Pearce element diagrams and the Chayes closure problem, Contrib. Mineral. Petrol., 99, 11-24, 1988.

Norin, E., Geological Explorations in Western Tibet, in Reports from the scientific Expedition to the Northwestem Provinces of China under the leadership of Dr. Sven Hedin, Publ. 29 (III), Geology 7, Tryckeri Aktiebolaget, Thule, 205 pp., Stockholm, 1946.

Pearce, J. A., and H. Mei, Volcanic rocks of the 1985 Geotraverse: Lhasa to Golmud, Philos. Trans. R. Soc. London Ser. A, 327, 169-201, 1988.

Pinet, C., and C. Jaupart, A thermal model for the distribution in space and time of the Himalayan granites, Earth Planet. Sci. Lett., 84, 87-99, 1987.

Salters, V., and N. Shimizu, World-wide occurrence of HFSE-depleted mantle, Geochim. Cosmochim. Acto, 52, 2177-2182, 1988.

Taylor, S. R., and S. M. McClennan, The Continental Crust: Its Composition and Evolution, 312, pp., Blackwell Scientific, Boston, Mass., 1985.

Thompson, A. B., Dehydration melting of Pelitic rocks and the generation of H2O-undersaturated granitic liquids, Am. J. Sci., 282, 1567-1595, 1982.

Turcotte, D. L., and G. Schubert, Geodynamics Applications of Continuum Physics to Geological Problems, John Wiley \& Sons, New York, 450 pp.

Vidal, P., A. Cocherie, and P. Le Fort, Geochemical investigations of the origin of the Manaslu leucogranite (Himalaya, Nepal), Geochim. Cosmochim. Acta, 46, 2279-2292, 1982.

Vielzeuf, D., and J. R. Holloway, Experimental determination of the fluid-absent melting relations in the pelitic system, Contrib. Mineral. Petrol., 98, 257-276, 1988.

Zartman, R. E., and B. R. Doe, Plumbotectonics-The model, Tectonophysics, 75, 135-162, 1981.

L.W. McKenna, J. D. Walker, Dept. of Geology, Univ. Kansas, Lawrence, KS 60045.

Received September 13, 1989;

revised January 17, 1990;

accepted January 23,1990 ) 